\title{
Core-Shell Magnetoactive PHB/Gelatin/Magnetite Composite Electrospun Scaffolds for Biomedical Applications
}

\author{
Artyom S. Pryadko ${ }^{1}$, Vladimir V. Botvin ${ }^{2}(D)$ Yulia R. Mukhortova ${ }^{1,2}$, Igor Pariy ${ }^{1}$, Dmitriy V. Wagner ${ }^{3}$ (D), \\ Pavel P. Laktionov ${ }^{4}$, Vera S. Chernonosova ${ }^{4}$ (D), Boris P. Chelobanov ${ }^{4,5}$, Roman V. Chernozem 1,2 (D), \\ Maria A. Surmeneva ${ }^{1,2}$, Andrei L. Kholkin ${ }^{2,6, * \mathbb{D}}$ and Roman A. Surmenev $1,2, * \mathbb{D}$
}

check for updates

Citation: Pryadko, A.S.; Botvin, V.V.; Mukhortova, Y.R.; Pariy, I.; Wagner, D.V.; Laktionov, P.P.; Chernonosova V.S.; Chelobanov, B.P.; Chernozem,

R.V.; Surmeneva, M.A.; et al. Core-Shell Magnetoactive PHB/Gelatin/Magnetite Composite Electrospun Scaffolds for Biomedical Applications. Polymers 2022, 14, 529. https://doi.org/10.3390/ polym14030529

Academic Editors: Satoshi Komasa Yoshiro Tahara, Tohru Sekino and Joji Okazaki

Received: 24 December 2021

Accepted: 26 January 2022

Published: 28 January 2022

Publisher's Note: MDPI stays neutral with regard to jurisdictional claims in published maps and institutional affiliations.

Copyright: (C) 2022 by the authors. Licensee MDPI, Basel, Switzerland. This article is an open access article distributed under the terms and conditions of the Creative Commons Attribution (CC BY) license (https:// creativecommons.org/licenses/by/ $4.0 /)$
1 Physical Materials Science and Composite Materials Center, Research School of Chemistry and Applied Biomedical Sciences, National Research Tomsk Polytechnic University, 634050 Tomsk, Russia; vilajer@gmail.com (A.S.P.); phenics100@gmail.com (Y.R.M.); igor-parij1995@mail.ru (I.P.); bigbbro@yandex.ru (R.V.C.); surmenevamaria@mail.ru (M.A.S.)

2 International Research and Development Center "Piezo- and Magnetoelectric Materials", Research School of Chemistry and Applied Biomedical Sciences, National Research Tomsk Polytechnic University, 634050 Tomsk, Russia; v.v.botvin@gmail.com

3 Faculty of Radiophysics, National Research Tomsk State University, 634050 Tomsk, Russia; wagner_dv@mail.ru

4 Institute of Chemical Biology and Fundamental Medicine, Siberian Branch, Russian Academy of Sciences, 630090 Novosibirsk, Russia; lakt@niboch.nsc.ru (P.P.L.); vera_mal@niboch.nsc.ru (V.S.C.); boris.p.chelobanov@gmail.com (B.P.C.)

5 Laboratory of Molecular Medicine, Novosibirsk State University, 630090 Novosibirsk, Russia

6 Department of Physics and CICECO-Aveiro Institute of Materials, University of Aveiro, 3810-193 Aveiro, Portugal

* Correspondence: kholkin@ua.pt (A.L.K.); rsurmenev@mail.ru (R.A.S.)

\begin{abstract}
Novel hybrid magnetoactive composite scaffolds based on poly(3-hydroxybutyrate) (PHB), gelatin, and magnetite $\left(\mathrm{Fe}_{3} \mathrm{O}_{4}\right)$ were fabricated by electrospinning. The morphology, structure, phase composition, and magnetic properties of composite scaffolds were studied. Fabrication procedures of $\mathrm{PHB} /$ gelatin and $\mathrm{PHB} /$ gelatin $/ \mathrm{Fe}_{3} \mathrm{O}_{4}$ scaffolds resulted in the formation of both core-shell and ribbon-shaped structure of the fibers. In case of hybrid $\mathrm{PHB} /$ gelatin $/ \mathrm{Fe}_{3} \mathrm{O}_{4}$ scaffolds submicronsized $\mathrm{Fe}_{3} \mathrm{O}_{4}$ particles were observed in the surface layers of the fibers. The X-ray photoelectron spectroscopy results allowed the presence of gelatin on the fiber surface (N/C ratio- -0.11$)$ to be revealed. Incubation of the composite scaffolds in saline for $3 \mathrm{~h}$ decreased the amount of gelatin on the surface by more than $\sim 75 \%$. The differential scanning calorimetry results obtained for pure PHB scaffolds revealed a characteristic melting peak at $177.5^{\circ} \mathrm{C}$. The presence of gelatin in $\mathrm{PHB} /$ gelatin and $\mathrm{PHB} /$ gelatin $/ \mathrm{Fe}_{3} \mathrm{O}_{4}$ scaffolds resulted in the decrease in melting temperature to $168-169{ }^{\circ} \mathrm{C}$ in comparison with pure PHB scaffolds due to the core-shell structure of the fibers. Hybrid scaffolds also demonstrated a decrease in crystallinity from 52.3\% (PHB) to 16.9\% (PHB/gelatin) and 9.2\% ( $\mathrm{PHB} /$ gelatin $/ \mathrm{Fe}_{3} \mathrm{O}_{4}$ ). All the prepared scaffolds were non-toxic and saturation magnetization of the composite scaffolds with magnetite was $3.27 \pm 0.22 \mathrm{emu} / \mathrm{g}$, which makes them prospective candidates for usage in biomedical applications.
\end{abstract}

Keywords: magnetoactive scaffold; poly-3-hydroxybutyrate; magnetite; composite; core-shell structure

\section{Introduction}

Functional materials responsive to different stimuli are of great importance for the well-being of modern society. Among all sources, various chemical and physical stimuli are currently being intensively investigated. Physical stimuli including magnetic or electric fields and ultrasound exposure have been of an interest in a variety of biomedical applications since they can remotely trigger a specific function of a biological object [1]. 
Magneto-responsive materials, as one of the representatives of the field responsive materials, have wide applications mainly in biomedicine (drug delivery, tissue engineering, biosensors, active diagnosis) [2], coatings (smart textiles and fibers) [3], and microelectronics (actuators, electromechanics) [4]. Functional magnetoactive materials are typically composites of polymers and inorganic fillers [5]. In terms of biomedical applications, magnetic filler of magneto-responsive materials, magnetite $\left(\mathrm{Fe}_{3} \mathrm{O}_{4}\right)$ and cobalt ferrite $\left(\mathrm{CoFe}_{2} \mathrm{O}_{4}\right)$ are used since they have a high saturation magnetization [6]. The latter, however, is potentially toxic to living tissues, which limits its widespread use in medicine [7]. On the contrary, magnetite is biocompatible, has relatively simple synthetic preparation procedures, and can be collected via magnetic separation [8].

As polymer components of magneto-responsive materials, polyethylene glycols, polyacrylamides [9], polyurethanes [10], fluorinated polymers [11], polyesters [12], and other polymers are used. Among the mentioned polymers, polyhydroxybutyrate (PHB) is of particular interest due to its biocompatibility, piezoelectricity, and ability to biodegrade [13]. Its degradation inside the body occurs slowly, thus, materials made of PHB are able to support a long-term tissue regeneration [14]. Moreover, D-3-hydroxybutyric acid-a degradation product of $\mathrm{PHB}$ - is a natural constituent of human blood that is nontoxic to body fluids and cause no inflammatory effects [15]. For this reason, PHB can be used as a drug carrier for the gradual and controlled release of the loaded drugs as well as a scaffold for the tissue engineering applications [16,17]. It has been shown that PHB based scaffolds are very attractive, especially for bone tissue engineering applications due to their piezoelectric properties $[18,19]$. Piezoelectricity plays an important role in bone tissue regeneration [20]. Piezoelectric polymers are able to modulate cellular behavior via surface charges generated in response to mechanical deformation. Furthermore, PHB can be embedded with magnetic particles to fabricate smart magneto-responsive materials providing physical stimulation of cells under a magnetic field [21,22]. Magneto-responsive scaffolds morphology, shape and geometry can be altered by the changes in strength and direction of the magnetic field to provide structural alignment [23], mechanical stimulation [24], and stem cell differentiation [25]. It has been shown that magneto-responsive materials are able to stimulate cell growth, proliferation and differentiation $[26,27]$. The potential applications of magneto-responsive materials for biomedical and tissue engineering applications have been summarized in recent reviews [28-30].

One of the drawbacks of PHB-based materials is the surface hydrophobicity. The hydrophobic properties of PHB, from the point of view of biomedical application, affect its controlled biodegradation, effective interactions with biological media, cells and different tissues [31,32]. The surface properties of PHB can be improved via various methods summarized elsewhere [13]. Among the methods known to increase the hydrophilicity of the PHB surface, the most promising is the preparation of blends with natural polymers [33], in particular, gelatin. Gelatin is a biodegradable and biocompatible polymer, which is in further hydrophilic, and non-antigenic. It also reveals plasticity and due to a combination of the properties mentioned, it is widely used in a variety of biomedical applications [34].

In the case of hybrid PHB-based materials, $\mathrm{PHB} / \mathrm{Fe}_{3} \mathrm{O}_{4}$ and $\mathrm{PHB} /$ gelatin composite scaffolds have been well studied [22,35-37]. They reveal magnetic properties and improved hydrophobicity, yet to the best of our knowledge, there have been no attempts yet to fabricate magnetoactive materials based on $\mathrm{PHB}$, gelatin, and $\mathrm{Fe}_{3} \mathrm{O}_{4}$. Thus, this work is devoted both to the fabrication of hybrid magneto-responsive PHB scaffolds doped with gelatin as well as doped with both gelatin and $\mathrm{Fe}_{3} \mathrm{O}_{4}$ and a comprehensive study of their structure, morphology, thermal, magnetic, and biological properties as prospective materials for a variety of biomedical applications.

\section{Materials and Methods}

\subsection{Materials}

Ferric (III) chloride hexahydrate $\left(\mathrm{FeCl}_{3}-6 \mathrm{H}_{2} \mathrm{O}\right.$, Sigma-Aldrich, Steinheim, Germany), ferric (II) sulfate heptahydrate $\left(\mathrm{FeSO}_{4}-7 \mathrm{H}_{2} \mathrm{O}\right.$, Sigma-Aldrich, Steinheim, Germany), 1,1,1,3,3,3- 
hexafluoroisopropanol (HFIP, Saint Louis, MO, USA), urea $\left(\left(\mathrm{NH}_{2}\right)_{2} \mathrm{CO}\right.$, Sigma-Aldrich, Steinheim, Germany), Poly(3-hydroxybutyrate) (PHB, natural origin, MW 500,000) and gelatin (from porcine skin, type A) were purchased from Merck (Sigma-Aldrich, Steinheim, Germany). Deionized water obtained by Millipore Milli-Q system (Darmstadt, Germany) was used in all experiments.

\subsection{Preparation and Characterization of Electrospun PHB/Gelatin/Magnetite Composite Scaffolds}

2.2.1. Synthesis of Magnetite Particles

Micron-sized $\mathrm{Fe}_{3} \mathrm{O}_{4}$ particles were synthesized by co-precipitation method. Briefly, $3.378 \mathrm{~g}$ of ferric (III) chloride hexahydrate, $1.713 \mathrm{~g}$ of ferric (II) sulfate heptahydrate and $6 \mathrm{~g}$ urea were loaded into a three-necked flask with a connected reflux condenser. Then, $50 \mathrm{~mL}$ of deionized water was added with constant stirring on a magnetic stirrer at a speed of $300 \mathrm{rpm}$ for $10 \mathrm{~min}$. The solution was then heated to $115^{\circ} \mathrm{C}$ for $18 \mathrm{~h}$ with stirring at $800 \mathrm{rpm}$ and then cooled to room temperature. The precipitate was separated by magnetic separation and decanted with deionized water to neutral $\mathrm{pH}$. The samples were dried at $35^{\circ} \mathrm{C}$ in a convection oven for two days.

\subsubsection{Electrospinning of Composite Fibrous Scaffolds}

For PHB based scaffolds, dry PHB polymer powder was dissolved in hexafluorisopropanol (HFIP) for $24 \mathrm{~h}$ to achieve the concentration of $5 \%(w / v)$ and then used as a control. For PHB/gelatin composites, 5\% $(w / v)$ PHB and 10\% $(w / v)$ gelatin solutions were used for electrospinning. For PHB/gelatin/ $\mathrm{Fe}_{3} \mathrm{O}_{4}$ composite scaffolds, $8 \%$ of $\mathrm{Fe}_{3} \mathrm{O}_{4}$ particles by weight of polymer were dispersed in HFIP and ultrasonicated (Scientz-IID, Ningbo SCienta Biotechnology Co. Ltd., Ningbo, China) for $4 \mathrm{~h}$ at room temperature. Then, $\mathrm{Fe}_{3} \mathrm{O}_{4}$ particles were added to the $\mathrm{PHB} /$ gelatin solution and got mixed with a shaker for $24 \mathrm{~h}$. Pure and composite PHB scaffolds were electrospun at the collector rotation speed of $200 \mathrm{rpm}$, voltage of $8-9 \mathrm{kV}$ and solution flow rate of $0.9 \mathrm{~mL} / \mathrm{h}$.

\subsection{Characterization of the Scaffolds}

The morphology of the particles and electrospun fibrous scaffolds was examined by a Scanning Electron Microscope (SEM) (EVO 10, Carl Zeiss AG, Jena, Germany). The obtained SEM images were used to calculate the diameters of magnetite particles and fibers using Image software (V. 1.8.0, National Institute of Health, Bethesda, MD, USA).

The effect of $\mathrm{Fe}_{3} \mathrm{O}_{4}$ particles on the crystal structure of $\mathrm{PHB}$ and composite scaffolds have been characterized by X-ray diffraction (XRD) using a XRD-6000 diffractometer (Shimadzu Corporation, Kyoto, Japan) with $\mathrm{CuK} \alpha$ radiation $(\lambda=0.154 \mathrm{~nm})$ in the $2 \theta$ range from $5^{\circ}$ to $65^{\circ}$ at a step size of $0.01^{\circ} / 2 \theta$ at $40 \mathrm{kV}$ and $30 \mathrm{~mA}$.

From the XRD patterns, the crystallite size $D$ of the crystalline phase of the scaffolds in the direction perpendicular to the (020) and (110) crystallographic plane was calculated using the Scherrer equation [38]:

$$
D=\frac{k \lambda}{\beta \cos \theta}
$$

where $k$ is proportionality constant, $\lambda$ is the $X$-ray wavelength $(\mathrm{nm}), \beta$ is the enlargement of the measured diffraction line at mid-height of its maximum intensity (in radian unit), and $\theta$ is the XRD peak position. The proportionality constant $k$ is a function of the geometrical shape of the crystal. When the geometry of the crystallites is not known, it is assumed to be spherical with $k$ being a value of 0.9 .

Raman spectra and optical photographs were recorded using NT MDT (NT-MDT Spectrum Instruments, Zelenograd, Russia) system equipped with a $100 \times$ objective. Excitation was performed with a $633 \mathrm{~nm}$ laser with a maximum power of $50 \mathrm{~mW}$. To prevent heating and oxidation of the magnetite particles, the laser power was reduced to $5 \mathrm{~mW}$.

To characterize the surface composition, X-ray photoelectron spectroscopy (XPS) was performed using a Thermo Fisher Scientific XPS NEXSA spectrometer (Thermo Fisher Scientific, Waltham, MA, USA) with a monochromated Al $\mathrm{K}_{\alpha}$ Alpha X-ray source working 
at $1486.6 \mathrm{eV}$. The XPS survey spectra were acquired at the pass energy $200(\mathrm{eV})$ and energy resolution $1 \mathrm{eV}$ from the surface area of $400 \mu \mathrm{m}^{2}$. The high-resolution spectra were acquired at the pass energy was $50(\mathrm{eV})$ and energy resolution $0.1(\mathrm{eV})$. The flood gun was used to compensate the charge. To estimate the amount of gelatin in the near-surface layer of the scaffold by the XPS method, a washing procedure was performed as follows. The scaffolds were incubated in $5 \mathrm{~mL}$ of saline for $2 \mathrm{~h}$ at $25^{\circ} \mathrm{C}$, then $2 \mathrm{~h}$ at $70{ }^{\circ} \mathrm{C}$. The scaffolds were then washed with deionized water 5 times for $20 \mathrm{~min}$. Incubation and washing were carried out with the constant stirring of liquids.

Differential scanning calorimetry (DSC) was performed on DSC Q2000 Instruments (TA Instruments, New Castle, DE, USA) at the range $50-250{ }^{\circ} \mathrm{C}$ in the nitrogen atmosphere at a heating rate of $10^{\circ} \mathrm{C} / \mathrm{min}$. Crystallinity $\left(\mathrm{X}_{\mathrm{C}}\right)$ of PHB scaffold and its composite with gelatin and magnetite was evaluated using the following formula:

$$
\mathrm{X}_{\mathrm{c}}=\frac{\Delta \mathrm{H}_{\mathrm{f}}}{\Delta \mathrm{H}_{\mathrm{f}}^{0}} \cdot 100 \% \text {, }
$$

where a heat of fusion for $100 \%$ crystalline $\operatorname{PHB}\left(\Delta \mathrm{H}_{\mathrm{f}}^{0}\right)$ equal $146 \mathrm{~J} \cdot \mathrm{g}^{-1}$ [39].

The magnetic properties of electrospun composite scaffolds were investigated at a temperature of $300 \mathrm{~K}$ with an external pulsed magnetic field from 0 to $6.5 \mathrm{kOe}$ using a vibrating sample magnetometer. The measurements were carried out according to the method described elsewhere [40].

The contact angle was measured on a Drop Shape Analyzer-DS A25 (Kruss GmbH, Hamburg, Germany) using water as a solvent (drop volume, $1 \mu \mathrm{L}$; shooting speed, 160 frames per second) and no less than 10 measurements per sample. Data presented as mean \pm error of the mean.

\subsection{Cell Cultivation and Determination of Scaffolds Cytotoxicity}

HeLa cells and human gingival fibroblasts (GF) were cultured in IMDM medium (Gibco, Carlsbad, CA, USA) containing 10\% fetal calf serum (Gibco, Carlsbad, CA, USA) and antibiotics penicillin and streptomycin $(100 \mathrm{U} / \mathrm{mL})$ in an atmosphere of $5 \% \mathrm{CO}_{2}$ at $37^{\circ} \mathrm{C}$. To assess the cytotoxicity of the obtained materials, disks $10 \mathrm{~mm}$ in diameter $\left(\sim 0.785 \mathrm{~cm}^{2}\right)$ were cut from the scaffolds using a custom-made device. The cytotoxicity of the materials was carried out according to ISO 10993-5:1999 «Biological evaluation of medical devices-Part 5: Tests for in vitro cytotoxicity» using extracts from the material and the method of direct contact. To determine cytotoxicity using extracts from the material, scaffolds (disks with a diameter of $10 \mathrm{~mm}$ ) were incubated in IMDM medium for 24 or $48 \mathrm{~h}$, and then cells cultured in 48 well plates were incubated with the obtained extracts for 24 or $48 \mathrm{~h}$, correspondingly. To determine the cytotoxicity of the scaffolds by direct contact, they were placed in the wells of a 48-well plate and fixed with Teflon rings. The cells were cultured on the scaffolds for 24 and $48 \mathrm{~h}$. To get a calibration curve for the AlamarBlue test, the cells were plated on a plastic plate at the rate of 100, 50, 25, and $12.5 \%$ of their number in the remaining wells, incubated in the presence of a medium that did not contact the materials. The medium was removed, the cells were washed, and the IMDM medium without phenol red, containing 10\% AlamarBlue dye, was added to them, incubated for $2-8 \mathrm{~h}$ at $37{ }^{\circ} \mathrm{C}$ and $5 \% \mathrm{CO}_{2}$, then the supernatant was transferred into 96-well plates and the optical density of the solution was measured at wavelength $570 \mathrm{~nm}$ and reference wavelength $620 \mathrm{~nm}$ on a Multiskan GO spectrophotometer (ThermoScientific, Waltham, MA, USA). Using Microsoft Excel (V. 2016, Microsoft, Redmond, WA, USA), the dependence of optical density from the number of planted cells was calculated. Then, using this formula, the relative percentage of viable cells for each individual disc was calculated, the average value was found and a subsequent diagram was built. The cells on scaffolds were fixed with a $4 \%$ formalin at $4{ }^{\circ} \mathrm{C}$ for $24 \mathrm{~h}$. Fixed cells rinsed with PBS, dehydrated using a graded ethanol series $(50,70,80,90,96$, and $100 \%)$ and then incubated in ethanol/hexamethyldisilazane (HMDS) solution (in a ratio at 1:1) followed by incubation in $100 \%$ HMDS. The samples were fixed on a sample stand using double-sided carbon tape 
and dried in air. The samples were sputter coated with $10 \mathrm{~nm}$ gold/palladium in SC7620 Mini Sputter Coater (Quorum Technologies, Laughton, UK) and analyzed using a SEM EVO 10 (Carl Zeiss AG, Jena, Germany) at an accelerating voltage of $10 \mathrm{kV}$.

GraphPad Prism software (V. 9.3.1, GraphPad Software, San Diego, CA, USA) was employed to analyze the statistical significance of the toxicity data and presented as described in [41]. Two-way analyses of variance (ANOVA) with Tukey's multiple comparison tests were thus applied. The entire determination values are expressed as means $\pm \mathrm{SD}$, and they were significantly considered at $p$-value $<0.05$, where $n=3$.

\section{Results}

3.1. Study of the Morphology, Structure and Physico-Chemical Properties of Pure and Composite PHB Scaffolds

The morphology and phase composition of synthesized $\mathrm{Fe}_{3} \mathrm{O}_{4}$ were studied by SEM, XRD, and Raman spectroscopy (Supplementary Materials, Figures S1 and S2). Synthesized $\mathrm{Fe}_{3} \mathrm{O}_{4}$ particles have a submicron size of $329 \pm 70 \mathrm{~nm}$ (Supporting Information, Figure S1). The XRD patterns of $\mathrm{Fe}_{3} \mathrm{O}_{4}$ (Supporting Information, Figure S2A) particles contain characteristic reflexes of magnetite at 2 Theta of 18.23, 30.0, 35.36, 42.99, 53.37, 56.87, and 62.45 corresponding to $\mathrm{d}_{\mathrm{hkl}}$ crystal planes at (111), (220), (311), (400), (422), (511), and (440), respectively. The crystallite size calculated by the Scherrer equation was $36.1 \mathrm{~nm}$. Raman spectrum (Supporting Information, Figure S2B) of $\mathrm{Fe}_{3} \mathrm{O}_{4}$ particles confirms the magnetite structure due to the presence of the peaks at 296,533, and $667 \mathrm{~cm}^{-1}$.

The effect of $\mathrm{Fe}_{3} \mathrm{O}_{4}$ particles and gelatin on the morphology of electrospun fibers was investigated via SEM. SEM images (Figure 1A-F) showed randomly-oriented bead-free microfibers with an average diameter of $1.75 \pm 0.26 \mu \mathrm{m}, 2.33 \pm 1.38 \mu \mathrm{m}$ and $5.65 \pm 1.23$ for $\mathrm{PHB}, \mathrm{PHB} /$ gelatin and $\mathrm{PHB} /$ gelatin $/ \mathrm{Fe}_{3} \mathrm{O}_{4}$ scaffolds, respectively.
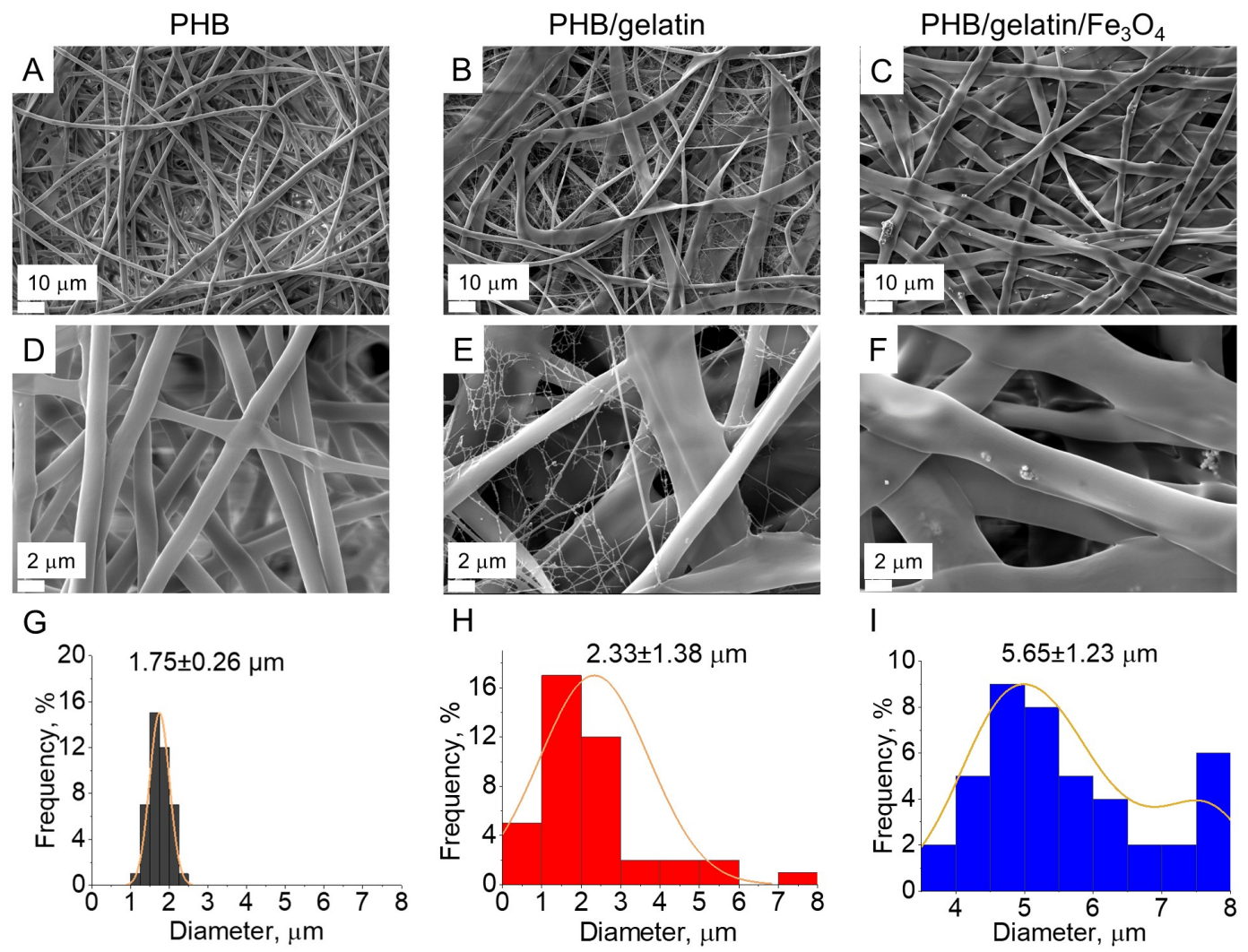

Figure 1. SEM images (A-F) and relative fiber diameter distributions (G-I) of the pure and hybrid scaffolds. 
The morphology of the composite fibers (Figure 1B,C,E,F) reveals a ribbon-like geometry upon addition of gelatin. Similar observation of the changes in the fiber morphology is reported elsewhere [42]. The formation of ribbon-shaped fibers was attributed to the rapid evaporation of the solvent from the fiber matrix. In case of hybrid $\mathrm{PHB} /$ gelatin $/ \mathrm{Fe}_{3} \mathrm{O}_{4} \mathrm{scaf}-$ folds (Figure 1C,F) small protrusions from the $\mathrm{Fe}_{3} \mathrm{O}_{4}$ particles situated close to the surface are observed. The addition of gelatin increased the fibers diameter of hybrid $\mathrm{PHB} /$ gelatin and $\mathrm{PHB} /$ gelatin/ $\mathrm{Fe}_{3} \mathrm{O}_{4}$ scaffolds (Figure $1 \mathrm{G}-\mathrm{I}$ ), which is associated with the increased viscosity and surface tension of the polymer solution [36]. Moreover, the surface charge density of the polymer solution may also affect fiber diameter and morphology of the electrospun fibers [43]. Similar observation of the fiber diameter increase is also reported elsewhere [44].

Structure, phase composition and other properties of pure and composite scaffolds were studied by XRD, Raman spectroscopy, XPS, and DSC. Figure 2A shows the XRD results on the structure and phase composition of the electrospun scaffolds. The obtained diffraction patterns of PHB scaffolds clearly show the main characteristic peaks of the crystalline phase of $\mathrm{PHB}$, observed at $2 \theta$ values of $13.6^{\circ}(020)$ and $16.9^{\circ}(110)$. The sample also contains the peaks at $21.4^{\circ}(101), 22.4^{\circ}(111), 25.5^{\circ}(031 / 130), 26.9^{\circ}(040)$ assigned to the planes of the $\alpha$-phase of PHB (ICDD PDF card No. 00-068-1411). The pronounced peaks observed for hybrid $\mathrm{PHB} /$ gelatin $/ \mathrm{Fe}_{3} \mathrm{O}_{4}$ scaffolds at $2 \theta 18.2^{\circ}$ (111), 30.4 $4^{\circ}(220), 35.9^{\circ}$ (311), $43.5^{\circ}(400), 53.5^{\circ}(422), 57.7^{\circ}(511), 63.1^{\circ}(440)$, which correspond to the magnetite with face-centered cubic lattice [45]. When blended and electrospun PHB along with gelatin, the XRD patterns indicated a decrease in the crystallite size (from $31 \mathrm{~nm}$ in PHB and $27 \mathrm{~nm}$ in $\mathrm{PHB}$ /gelatin to $21 \mathrm{~nm}$ in $\mathrm{PHB} /$ gelatin/ $\mathrm{Fe}_{3} \mathrm{O}_{4}$ for (020) plane) of the obtained composite scaffolds [36].
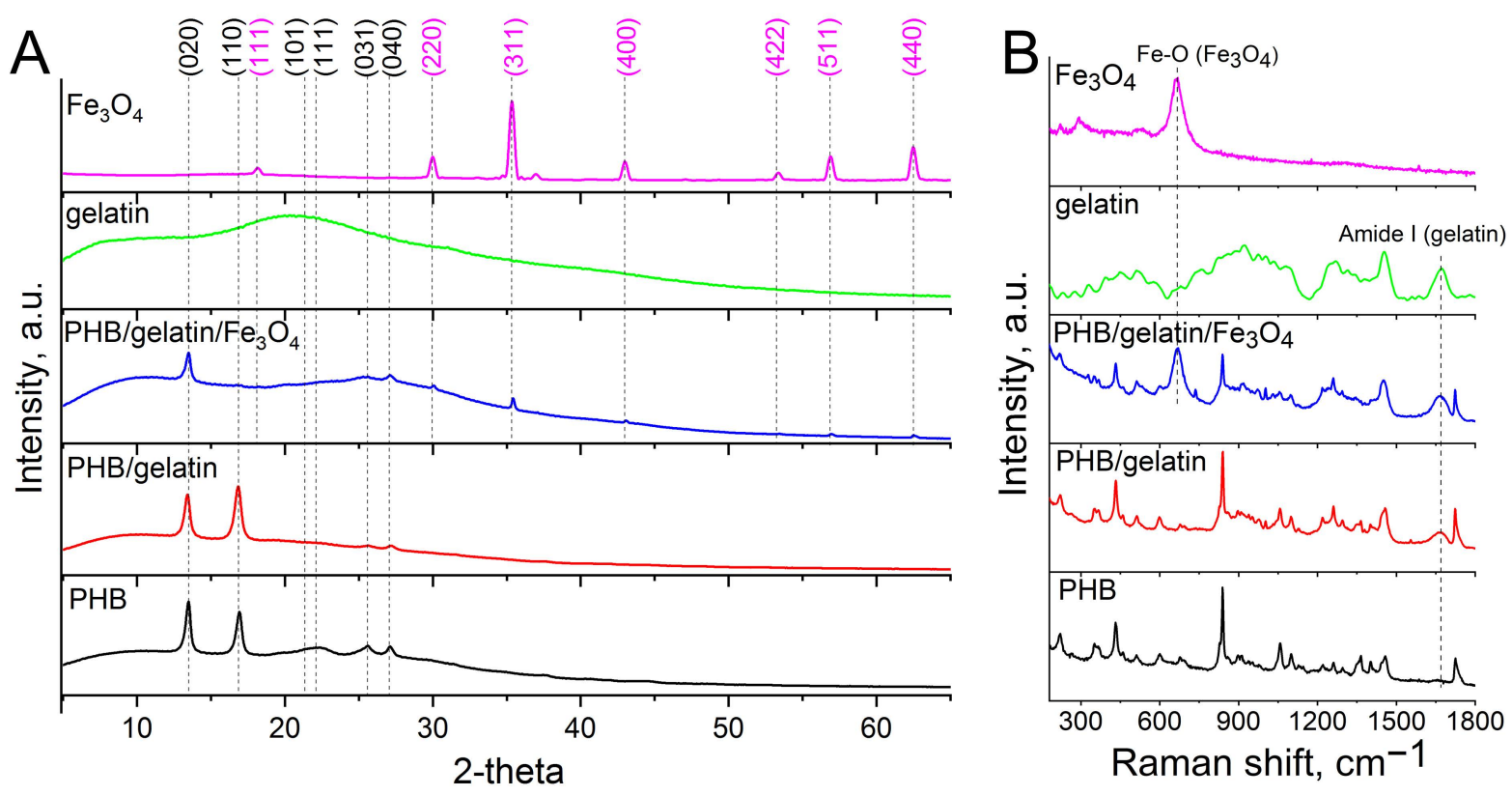

Figure 2. XRD patterns (A) and Raman spectra (B) of composite scaffolds.

Also, after the addition of the $\mathrm{Fe}_{3} \mathrm{O}_{4}$ particles in the polymer matrix, the intensity of the peak at $13.6^{\circ}$ decreased, which was ascribed to inhibition of the polymer crystallization process caused by the magnetic particles decreasing the volume fraction of the crystalline phase in the fibers $[35,46]$ (for more details please address to the DSC section of this study). Thus, submicron-sized $\mathrm{Fe}_{3} \mathrm{O}_{4}$ particles strongly affect the structure of $\mathrm{PHB}$, changing the rate of polymer crystallization, polymer chains mobility and thus limiting the growth of lamellas [47]. 
Raman spectra of hybrid $\mathrm{PHB} /$ gelatin and $\mathrm{PHB} /$ gelatin/ $/ \mathrm{Fe}_{3} \mathrm{O}_{4}$ scaffolds contain characteristic amide I peak at $1660 \mathrm{~cm}^{-1}$ and low intensity amide II peak at $1555 \mathrm{~cm}^{-1}$ confirming the presence of gelatin in the scaffolds (Figure 2B) [48]. The Raman spectra of PHB scaffolds exhibited the characteristic peaks presented in Table 1.

Table 1. Characteristic Raman shifts of PHB scaffolds.

\begin{tabular}{|c|c|c|c|}
\hline $\begin{array}{c}\text { Raman Shift, } \\
\mathrm{cm}^{-1}\end{array}$ & Assignments & $\begin{array}{c}\text { Raman Shift, } \\
\mathrm{cm}^{-1}\end{array}$ & Assignments \\
\hline 1725 & $\begin{aligned} \mathrm{C}= & \text { O stretching vibrations } \\
& (\text { crystalline phase })\end{aligned}$ & 1058 & $\mathrm{C}-\mathrm{O}$ stretching vibrations \\
\hline 1460 & $\begin{array}{l}\mathrm{CH}_{3} \text { asymmetric bending } \\
\text { vibrations }\end{array}$ & 953 & $\begin{array}{c}\mathrm{C}-\mathrm{C} \text { stretching vibrations } \\
\text { and } \mathrm{CH}_{3} \text { rocking bending } \\
\text { vibrations }\end{array}$ \\
\hline 1443 & $\mathrm{CH}_{2}$ bending vibrations & 841 & $\begin{array}{l}\text { C-COO stretching } \\
\text { vibrations }\end{array}$ \\
\hline 1402 & $\begin{array}{c}\mathrm{CH}_{3} \text { symmetric bending } \\
\text { vibrations }\end{array}$ & 691 & $\begin{array}{c}\mathrm{C}=\mathrm{O} \text { bending vibrations } \\
\text { (in plane) }\end{array}$ \\
\hline 1365 & $\begin{array}{l}\mathrm{CH} \text { bending vibrations } \\
\text { and } \mathrm{CH}_{3} \text { symmetric } \\
\text { bending vibrations }\end{array}$ & 680 & $\begin{array}{c}\mathrm{C}=\mathrm{O} \text { bending vibrations } \\
\text { (out of plane) }\end{array}$ \\
\hline 1295 & $\mathrm{CH}$ bending vibrations & 598 & $\begin{array}{l}\mathrm{C}-\mathrm{CH}_{3} \text { and } \mathrm{CCO} \\
\text { bending vibrations }\end{array}$ \\
\hline 1261 & $\begin{array}{l}\mathrm{C}-\mathrm{O}-\mathrm{C} \text { stretching } \\
\text { vibrations and } \mathrm{CH} \\
\text { bending vibrations }\end{array}$ & 510 & $\begin{array}{l}\mathrm{C}-\mathrm{CH}_{3} \text { and } \mathrm{CCO} \\
\text { bending vibrations }\end{array}$ \\
\hline 1220 & $\begin{array}{l}\text { COC asymmetric } \\
\text { stretching vibrations }\end{array}$ & 367 & $\begin{array}{l}\mathrm{C}-\mathrm{CH}_{3} \text { and } \mathrm{CCO} \\
\text { bending vibrations }\end{array}$ \\
\hline 1101 & $\begin{array}{c}\text { COC symmetric } \\
\text { stretching vibrations }\end{array}$ & 351 & $\begin{array}{l}\mathrm{C}-\mathrm{CH}_{3} \text { and } \mathrm{CCO} \\
\text { bending vibrations }\end{array}$ \\
\hline
\end{tabular}

The spectrum of $\mathrm{PHB} /$ gelatin $/ \mathrm{Fe}_{3} \mathrm{O}_{4}$ scaffold includes magnetite shift at $\sim 670 \mathrm{~cm}^{-1}$ (Fe-O sym. str). Other less intensive peaks of magnetite at $540 \mathrm{~cm}^{-1}$ and $310 \mathrm{~cm}^{-1}$ are not observed in the composite scaffolds since they overlap with the reflexes of PHB.

To reveal the changes in the surface composition of the PHB scaffolds after the addition of gelatin and $\mathrm{Fe}_{3} \mathrm{O}_{4}$ particles, XPS analysis was performed (Figure 3D). As observed, pure $\mathrm{PHB}$ scaffolds demonstrated the presence of $\mathrm{C}$ 1s and $\mathrm{O}$ 1s regions typical for PHB polymer [49]. In turn, the addition of gelatin in the polymer solution before electrospinning resulted in the presence of the pronounced peak of nitrogen associated with amine and amide group of gelatin [50], as well as a low intensity peaks of $\mathrm{Na}, \mathrm{S}, \mathrm{F}, \mathrm{Ca}$, and $\mathrm{Cl}$ elements most likely corresponding to salt contaminations of gelatin. It is worth mentioning that no iron was detected in the XPS spectra. At the same time, the optical and SEM images clearly demonstrated the presence of $\mathrm{Fe}_{3} \mathrm{O}_{4}$ particles inside the fibers (Figure 3C). Taking into account an XPS sensitive depth of up to $10 \mathrm{~nm}$ for polymers [51], $\mathrm{Fe}_{3} \mathrm{O}_{4}$ particles were inside the polymer fibers deeper than the sensitivity of the XPS analysis. In turn, the observed presence of $\mathrm{N} 1 \mathrm{~s}$ can be explained by the formation of a gelatin thin coating on the surface of the fibers (Figure 3D). 


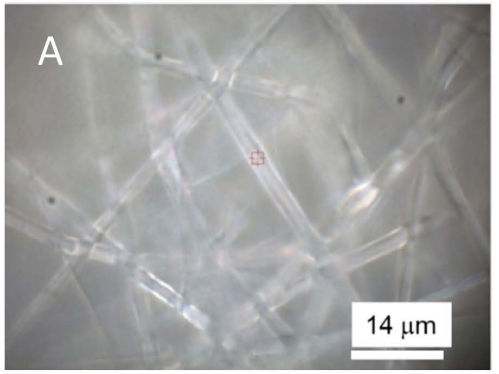

D $\mathrm{PHB} /$ gelatin/ $/ \mathrm{Fe}_{3} \mathrm{O}_{4}$

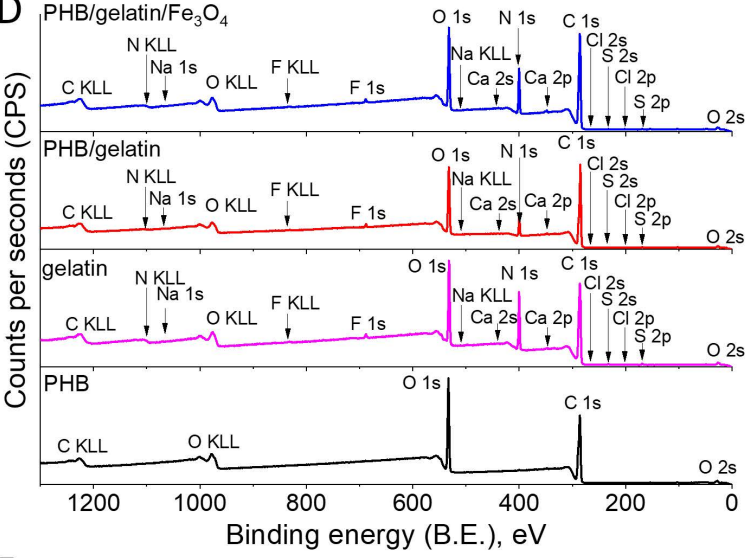

F

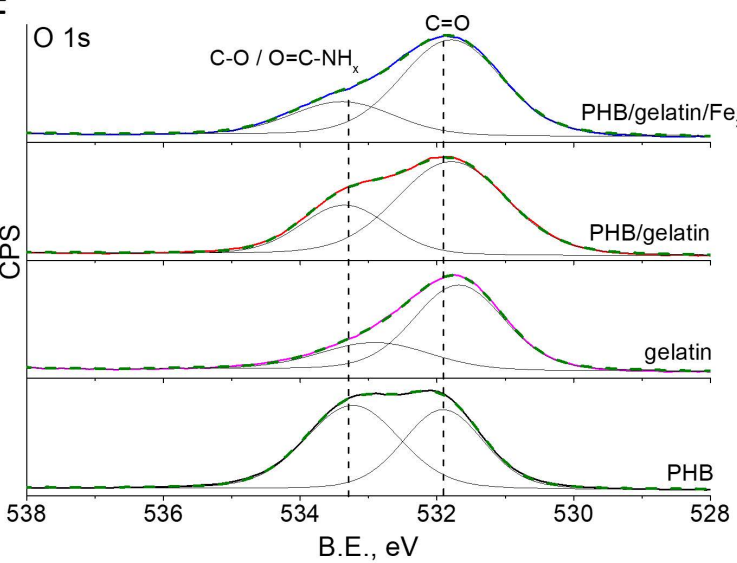

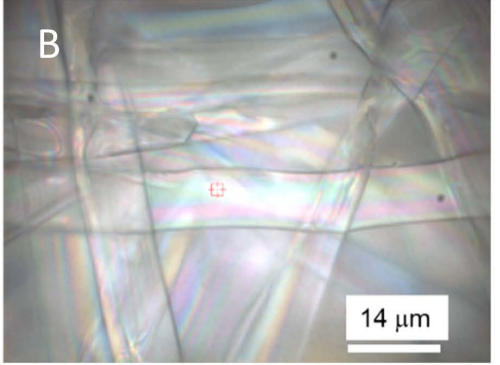

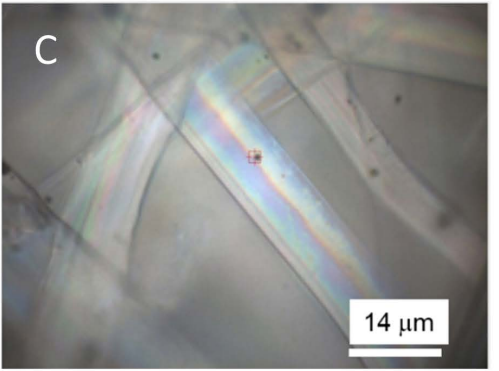

E

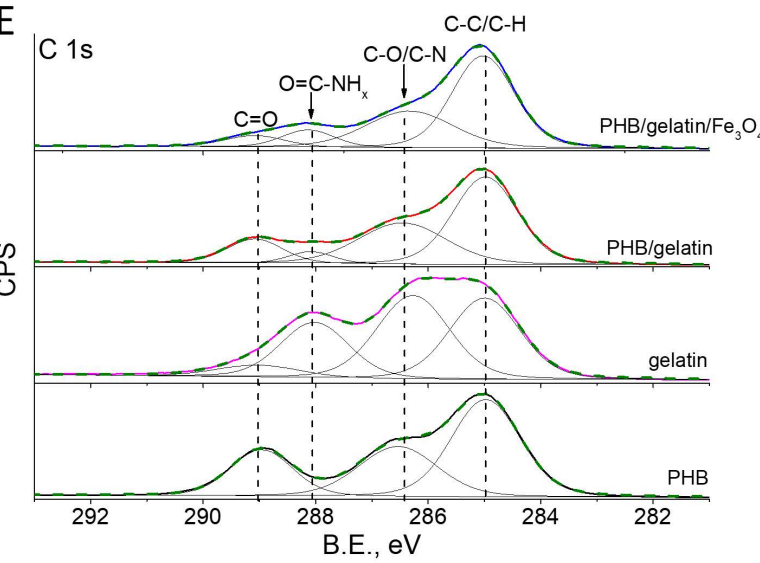

G

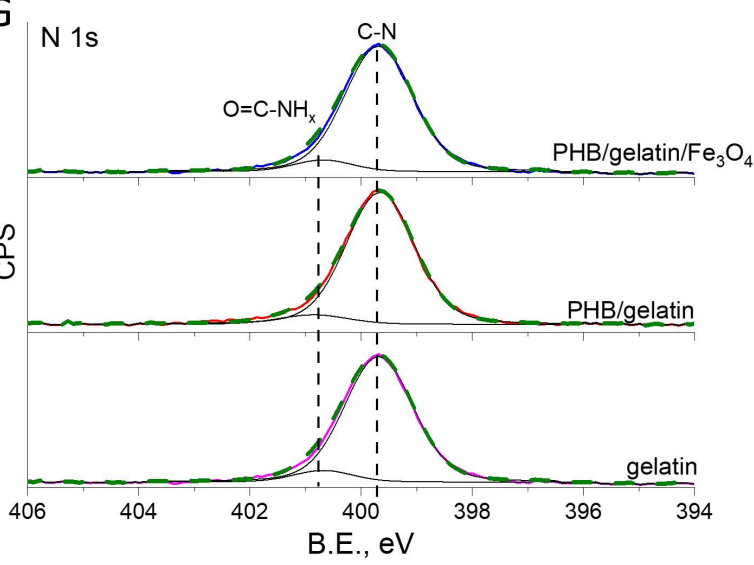

Figure 3. Optical microscope photographs (A-C) of pure PHB (A), PHB/gelatin (B) and $\mathrm{PHB} /$ gelatin $/ \mathrm{Fe}_{3} \mathrm{O}_{4}$ scaffolds (C). Survey XPS spectra of the synthesized pure $\mathrm{PHB}, \mathrm{PHB} /$ gelatin and $\mathrm{PHB} /$ gelatin $/ \mathrm{Fe}_{3} \mathrm{O}_{4}$ scaffolds (D). High-resolution XPS spectra of $\mathrm{C} 1 \mathrm{~s}, \mathrm{O} 1 \mathrm{~s}$ and $\mathrm{N}$ 1s regions for pure gelatin, pure $\mathrm{PHB}$ and composite scaffolds with addition of gelatin and $\mathrm{Fe}_{3} \mathrm{O}_{4}(\mathrm{E}-\mathrm{G})$.

Table 2 shows relative atomic concentrations of the detected carbon, oxygen and nitrogen, as well as salts mentioned as 'others' (F, S, Na, Ca, and $\mathrm{Cl}$ ). As seen, the contribution of the salts was lower than $2 \%$ for synthesized pure gelatin and hybrid scaffolds. Additionally, the $\mathrm{N} / \mathrm{C}$ ratio dropped twice for the composite scaffolds compared to the pure gelatin, most likely due to the contribution of the polymer. Therefore, this result indicates the presence of a very thin gelatin enriched layer on the fibers' surface, since XPS sensitive depth varies up to $10 \mathrm{~nm}$ for polymer [51]. 
Table 2. Relative atomic concentrations of the observed elements on the surface of the scaffolds and $\mathrm{N} / \mathrm{C}$ ratio. Others include salt contamination corresponding to $\mathrm{Ca}, \mathrm{F}, \mathrm{S}, \mathrm{Na}$, and $\mathrm{Cl}$.

\begin{tabular}{|c|c|c|c|c|c|}
\hline \multirow{2}{*}{ Composite } & \multicolumn{4}{|c|}{ Relative Atomic Concentration, $\%$} & \multirow{2}{*}{ N/C Ratio } \\
\hline & C 1s & O 1s & N 1s & Others & \\
\hline PHB & 74 & 26 & - & - & - \\
\hline Gelatin & 66 & 17 & 15 & $>2$ & 0.23 \\
\hline PHB/gelatin & 72 & 20 & 7 & $>1$ & 0.10 \\
\hline $\mathrm{PHB} /$ gelatin $/ \mathrm{Fe}_{3} \mathrm{O}_{4}$ & 75 & 15 & 8 & $>2$ & 0.11 \\
\hline PHB/gelatin (washed) & 74 & 24 & 2 & $\mathrm{n} / \mathrm{a}$ & 0.03 \\
\hline $\mathrm{PHB} /$ gelatin $/ \mathrm{Fe}_{3} \mathrm{O}_{4}$ (washed) & 74 & 24 & 2 & $\mathrm{n} / \mathrm{a}$ & 0.03 \\
\hline
\end{tabular}

To verify this suggestion, the water treatment of the scaffolds with gelatin was performed after electrospinning (Supporting Information, Figure S3). As a result, the N/C ratio dropped from $0.10-0.11$ to 0.03 , thereby indicating the dissolution of a gelatin layer from the fibers surface (Table 2). Furthermore, other salts were not detected after composite scaffolds were immersed in saline solution. Additionally, the decrease in the intensity of $\mathrm{O}=\mathrm{C}-\mathrm{CH}$ peak at $288.1 \mathrm{eV}$ from gelatin was observed in the high-resolution XPS spectra of the $\mathrm{C} 1 \mathrm{~s}$ region for $\mathrm{PHB} /$ gelatin and $\mathrm{PHB} /$ gelatin $/ \mathrm{Fe}_{3} \mathrm{O}_{4}$ scaffolds (Supporting Information, Figure S3B). At the same time, the intensity of a peak at $533.3 \mathrm{eV}$ in $\mathrm{O} 1 \mathrm{~s}$ region of hybrid scaffolds increased after exposure to saline solution in comparison with as-electrospun composite scaffolds, thereby indicating the dominant contribution from C-O group of $\mathrm{PHB}$ (Supporting Information, Figure S3C).

The analysis of high-resolution XPS spectra revealed chemical bonds on the surface of the scaffolds, as shown in Figure 3E-G. The $\mathrm{C}$ 1s region of PHB scaffolds was fitted with three typical peaks at $285 \mathrm{eV}$ (C-C/C-H), $286.5 \mathrm{eV}(\mathrm{C}-\mathrm{O})$ and $289 \mathrm{eV}(\mathrm{C}=\mathrm{O})$ (Figure 3E) [49,52]. Taking into account the presence of the same functional groups, $\mathrm{C} 1 \mathrm{~s}$ region of gelatin demonstrated the additional peak at $288.1 \mathrm{eV}$, which is assigned to $\mathrm{O}=\mathrm{C}-\mathrm{CH}$ groups [53-55]. Furthermore, in contrast to $\mathrm{PHB}$, the higher intensity of the peak at $286.5 \mathrm{eV}$ in $\mathrm{C} 1 \mathrm{~s}$ region of gelatin is explained by the contribution of $\mathrm{C}-\mathrm{N}$ groups [54]. In turn, $\mathrm{C} 1 \mathrm{~s}$ regions of all hybrid PHB-based scaffolds with the addition of gelatin and $\mathrm{Fe}_{3} \mathrm{O}_{4}$ were deconvoluted with a pronounced presence of $\mathrm{O}=\mathrm{C}-\mathrm{CH}$ group. Therefore, the contribution of this functional group can be excluded from the peak at $533.3 \mathrm{eV}$ in $\mathrm{O} 1 \mathrm{~s}$ region of hybrid scaffolds [53], which demonstrated the reduced intensity of this peak in comparison with the $\mathrm{C}=\mathrm{O}$ peak of pure PHB scaffolds (Figure 3F) [49]. Meanwhile, the N 1s region confirmed the presence of both $\mathrm{O}=\mathrm{C}-\mathrm{CH}$ group and $\mathrm{C}-\mathrm{N}$ group in the hybrid scaffolds (Figure 3G) [53].

More details on the structure of the prepared scaffolds were revealed using a DSC analysis. The obtained DSC curves for pure $\mathrm{PHB}, \mathrm{PHB} /$ gelatin, and $\mathrm{PHB} /$ gelatin $/ \mathrm{Fe}_{3} \mathrm{O}_{4}$ scaffolds are presented in Figure 4. In the case of pure PHB scaffold, a characteristic endothermic peak of $177.5^{\circ} \mathrm{C}$ corresponding to the melting temperature of the polymer is found [56]. The presence of gelatin in $\mathrm{PHB} /$ gelatin and $\mathrm{PHB} /$ gelatin $/ \mathrm{Fe}_{3} \mathrm{O}_{4}$ scaffolds results in the decrease in melting temperature to $168-169^{\circ} \mathrm{C}$ compared with pure PHB scaffold. It is reported that gelatin and PHB are thermodynamically immiscible polymers, therefore, phase separation occurs during elecrospinning leading to the formation of coreshell structure (PHB-core, gelatin-shell) [57]. Due to polyelectrolyte (polyampholyte) nature of gelatin, it tends to migrate in a similar manner as other polyelectrolytes towards the outer layer of the $\mathrm{PHB} /$ gelatin solution jet under the electrostatic repulsion forming shell layer [58]. Additionally, the interference observed in the optical images (Figure 3B,C) and XPS spectra of composite fibers with gelatin (Figure $3 \mathrm{D}-\mathrm{G}$ ) confirm the presence of a gelatin layer on the surface of PHB fibers. Therefore, the changes in melting temperature may be associated with the core-shell structure of the fibers affecting the heat transfer from the gelatin layer to the PHB core. The DSC curve of pure gelatin has no melting peak due to its amorphous nature. The curve includes a broad endothermic peak assigned as a denaturation temperature [59]. The obtained data of enthalpy of fusion and crystallinity are shown in Table 3. 


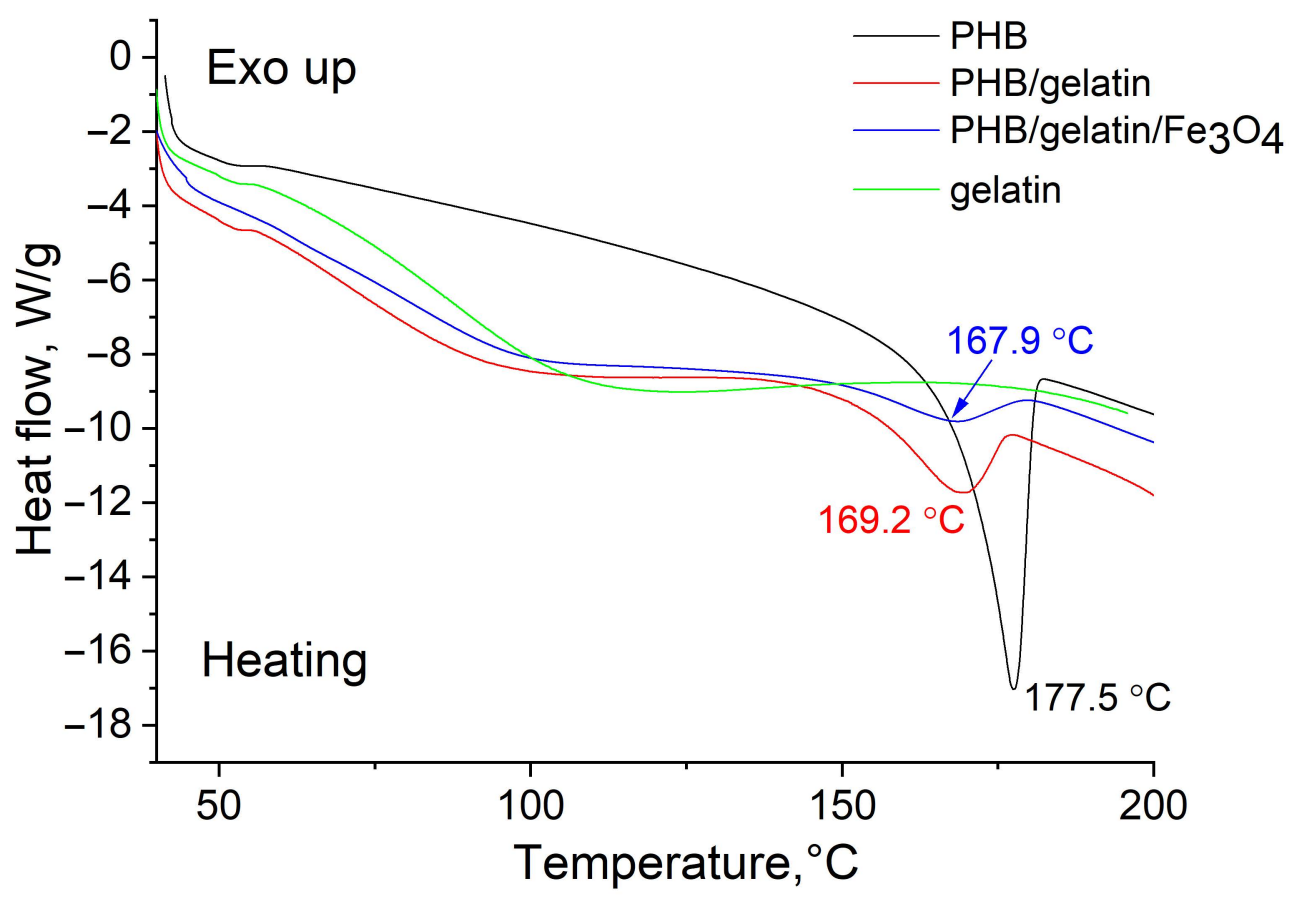

Figure 4. DSC curves obtained for pure gelatin as well as pure $\mathrm{PHB}, \mathrm{PHB} /$ gelatin, $\mathrm{PHB} /$ gelatin/ $\mathrm{Fe}_{3} \mathrm{O}_{4}$ scaffolds.

Table 3. The DSC results obtained for the composite scaffolds.

\begin{tabular}{cccc}
\hline Sample & $\mathbf{T}_{\mathbf{m}},{ }^{\circ} \mathbf{C}$ & $\mathbf{\Delta H}_{\mathbf{m}}, \mathbf{J} / \mathbf{g}$ & $\mathbf{X}_{\mathbf{c}}, \mathbf{\%}$ \\
\hline PHB & 177.5 & 76.3 & 52.3 \\
PHB/gelatin & 169.2 & 24.7 & 16.9 \\
PHB/gelatin $/ \mathrm{Fe}_{3} \mathrm{O}_{4}$ & 167.9 & 13.4 & 9.2 \\
gelatin & - & - & - \\
\hline
\end{tabular}

Crystallinity of pure PHB scaffolds is in agreement with the data presented in the literature [56]. The composite $\mathrm{PHB} /$ gelatin and $\mathrm{PHB} /$ gelatin $/ \mathrm{Fe}_{3} \mathrm{O}_{4}$ demonstrated a decrease in crystallinity. This tendency can be explained by the formation of a thin gelatin layer (shell), which prevents the crystallization of PHB (confinement effect). The incorporation of submicron $\mathrm{Fe}_{3} \mathrm{O}_{4}$ particles into the scaffolds also promotes a decrease in crystallinity of PHB.

Magnetic properties of the composites are affected by the phase composition, crystallite size and particles dimension [60]. It is known that the saturation magnetization increases with the increase in the particle and crystallite sizes. The saturation magnetization of magnetoactive composites, which reveals a positive effect on cell differentiation and tissue growth ranges from 2 to $5 \mathrm{emu} / \mathrm{g}$ [61-63]. For instance, poly(l-lactide) $/ \mathrm{Fe}_{3} \mathrm{O}_{4}$ nanofibers exposed to a static magnetic field (SMF) of $100 \mathrm{mT}$ possessed enhanced osteogenic differentiation of MC3T3-E1 cells compared to non-exposed ones [62]. In other work, electrospun poly(lactide-co-glycolide) scaffolds embedded with oleic acid-coated iron oxide nanoparticles were seeded with mouse pre-osteoblasts (MC3T3-E1 cell line) to investigate the effect of static magnetic field [61]. It has been shown that SMF exposure of $70-80 \mathrm{mT}$ significantly improved cell attachment and osteogenic differentiation of mouse pre-osteoblasts as a result of the magnetically actuated mechanical stimuli induced through the nano-deformation of the magneto-responsive scaffolds.

In order to estimate the prospective use of the developed scaffolds in medicine, the saturation magnetization values of the scaffolds was measured. The saturation magnetization for the composite $\mathrm{PHB} /$ gelatin $/ \mathrm{Fe}_{3} \mathrm{O}_{4}$ scaffolds was $3.27 \pm 0.22 \mathrm{emu} / \mathrm{g}$ (Figure 5, 
inset image), whereas saturation magnetization of submicron-sized $\mathrm{Fe}_{3} \mathrm{O}_{4}$ particles was $103 \mathrm{emu} / \mathrm{g}$.

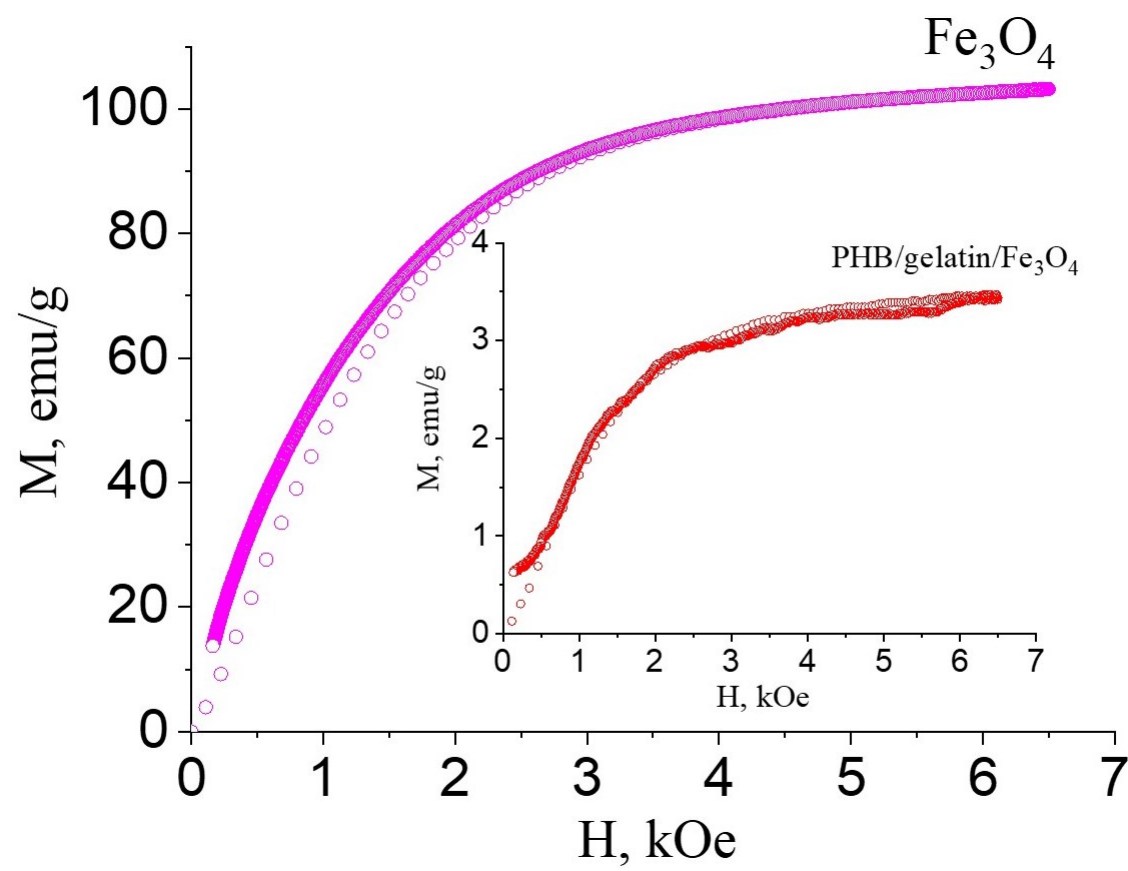

Figure 5. Magnetization curves of the $\mathrm{Fe}_{3} \mathrm{O}_{4}$ particles and composite $\mathrm{PHB} /$ gelatin $/ \mathrm{Fe}_{3} \mathrm{O}_{4}$ scaffolds (inset image).

The saturation magnetization of magnetite particles in our research is a little higher than that reported in the literature [64] due to the presence in the samples of superparamagnetic particles (paraprocess) and the ordering of the magnetic moments of the surface layer, which possesses some structural defects. Saturation magnetization of the composite electrospun scaffolds obtained in this study is in the range of $2-5 \mathrm{emu} / \mathrm{g}$ reported in the literature for the different magnetoactive composites, thus, they can be potentially used for tissue engineering and regenerative medicine applications using external magnetic field [61-63].

\subsection{Determination of Cytotoxicity of the Pure and Composite Scaffolds}

The cytotoxicity of electrospun scaffold was evaluated by the extraction test (ISO 10993-5:1999) using primary and transformed cell lines and two time intervals (24 and $48 \mathrm{~h}$ ). Longer incubation of the scaffolds in the culture medium provides better extraction of potentially toxic products, whereas a longer incubation of the extract with cells must increase the influence of potentially toxic substances on cell viability. It should also be mentioned that primary cells are usually more sensitive to toxic compounds or the culture medium composition that transformed the cells [65]. Human cervix adenocarcinoma HeLa cells and human primary fibroblasts demonstrated similar cellular responses to the extracts, which are not statistically different from that of the control scaffolds (PHB/gelatin compared with $\mathrm{PHB} /$ gelatin $\left./ \mathrm{Fe}_{3} \mathrm{O}_{4}\right)$. As such, the scaffolds can be considered as non-toxic to cells (Figure 6A). The statistically significant differences of PHB scaffolds from both $\mathrm{PHB} /$ gelatin and $\mathrm{PHB} /$ gelatin $/ \mathrm{Fe}_{3} \mathrm{O}_{4}$ scaffolds, which are more prominent at $48 \mathrm{~h}$ of cell cultivation, is obviously connected to the release of gelatin from the scaffolds, as shown for similar materials elsewhere [66]. Gelatin added to the culture medium can interfere with cell adhesion, demonstrating more pronounced effect at longer incubation times. This effect is observed on HeLa and more sensitive GF cells although this is not connected with the toxicity of $\mathrm{Fe}_{3} \mathrm{O}_{4}$ particles. 


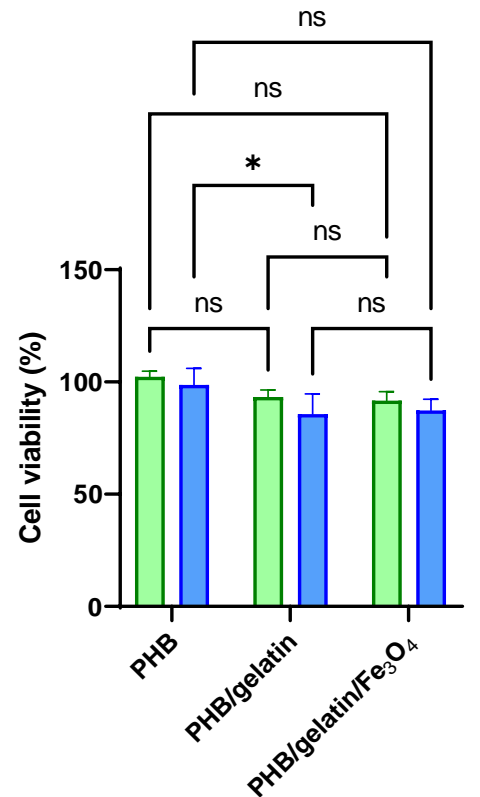

(A)

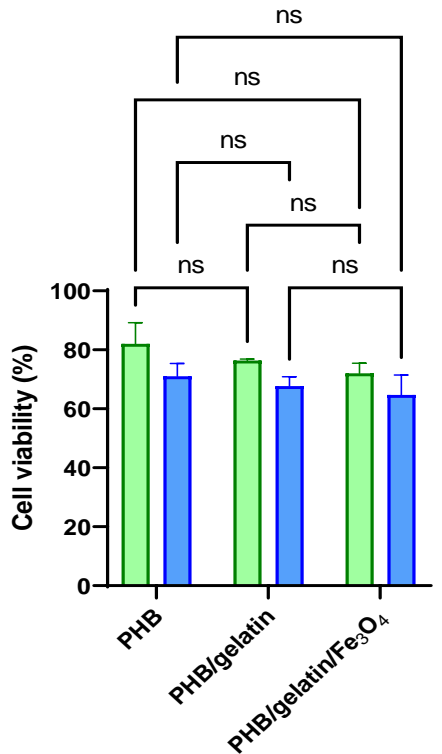

(C)

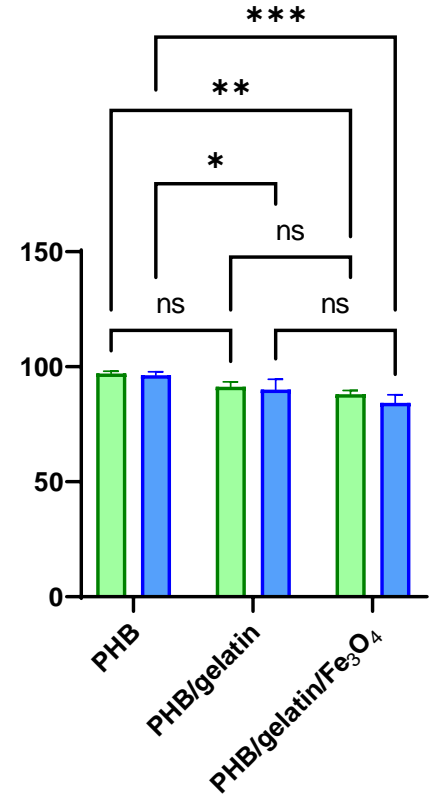

(B)

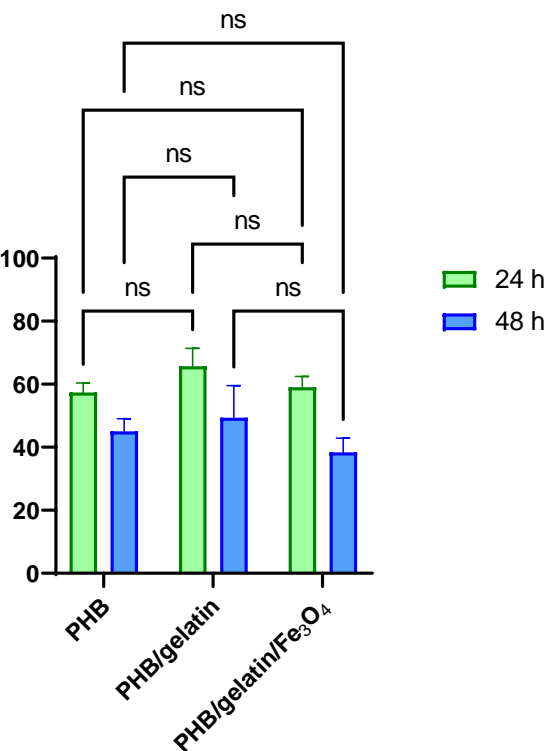

(D)

Figure 6. Cytotoxicity of pure $\mathrm{PHB}, \mathrm{PHB} /$ gelatin, $\mathrm{PHB} /$ gelatin/ $\mathrm{Fe}_{3} \mathrm{O}_{4}$ scaffolds for $\mathrm{HeLa}(\mathrm{A}, \mathrm{C})$ and GF (B,D) cells. The data obtained in accordance to ISO 10993-5:1999 using extracts from the material $(\mathbf{A}, \mathbf{B})$ and the method of direct contact $(\mathbf{C}, \mathbf{D})$. Cells seeded in the same number on tissue culture plastic were used as a control $(100 \%)$. Results are presented as means $\pm \operatorname{SD~}\left({ }^{* *} p<0.001,{ }^{* *} p<0.01\right.$, * $p<0.05$, and (ns) points to a non-significant difference).

This claim is supported by the cultivation of cells on the scaffolds, which demonstrated the absence of the toxicity independent on the scaffold composition. The number of HeLa cells adhered on the scaffolds surface almost did not depend on their composition, whereas GF cells were more susceptible to scaffolds composition and adhered better to PHB/gelatin ones. It should be mentioned that gelatin was removed partially from the fibers while being washed in saline solution, however residual quantities of gelatin nevertheless still supported GF cells adhesion. Actually, surface associated proteins can leave the fibers if they are not fixed by bifunctional reagents as well as crosslinking of proteins exposed at the fiber surface by bifunctional reagents, not only prevents their loss but promotes the 
increase in cell adhesion. The decrease in protein motility can be the reason of better cell adhesion $[66,67]$. HeLa cells adhered well to all types of scaffold, however the cells were spread better on the surface of PHB/gelatin as compared to other materials (Figure 7B). GF cells also spread better on PHB/gelatin matrices, forming multiple outgrowths probably due to the presence of a small diameter of the fibers in scaffolds. Despite the fact the XPS data demonstrated the absence of direct exposure of magnetite on the fiber surface and the results of better hydrophilicity of such scaffolds, HeLa cells have more pronounced granular boundaries on matrices with magnetite (Figure 7C). The contact angle decreased in $\mathrm{PHB}, \mathrm{PHB} /$ gelatin and $\mathrm{PHB} /$ gelatin $/ \mathrm{Fe}_{3} \mathrm{O}_{4}$ scaffolds from $92.14 \pm 2.21^{\circ}$ to $85.94 \pm 3.95^{\circ}$ and $81.77 \pm 3.23^{\circ}$, respectively. Perhaps this phenomenon is associated with the poorer protein adsorption on hydrophilic surfaces $[68,69]$, which leads to a minor decrease in cell adhesion to $\mathrm{PHB} /$ magnetite scaffolds. It should also be mentioned that, along with the chemical composition, the roughness and porosity of the matrices are the factors that determine the interaction of cells with scaffolds, namely, cell adhesion, proliferation, and migration $[70,71]$. The roughness within the range of $10-135 \mathrm{~nm}$ insignificantly influences the cell ability to attach to the matrix surface although a roughness exceeding $287 \mathrm{~nm}$ is rather inappropriate for cells to attach to [72,73]. Another factor that determines the colonization of scaffolds is the pore size, which influences the mechanism of cell-matrix interaction [74] and has had a stronger effect than the fiber diameter on the proliferation of dermal fibroblasts [75]. An insignificantly less efficient adhesion of GF cells toward the hybrid $\mathrm{PHB} /$ gelatin $/ \mathrm{Fe}_{3} \mathrm{O}_{4}$ scaffolds (Figures 6 and 7) may be explained not only by the chemical composition of the materials, but by considering the flat fibers are located further apart from each other when compared with other fibrous scaffolds (Figure 1).
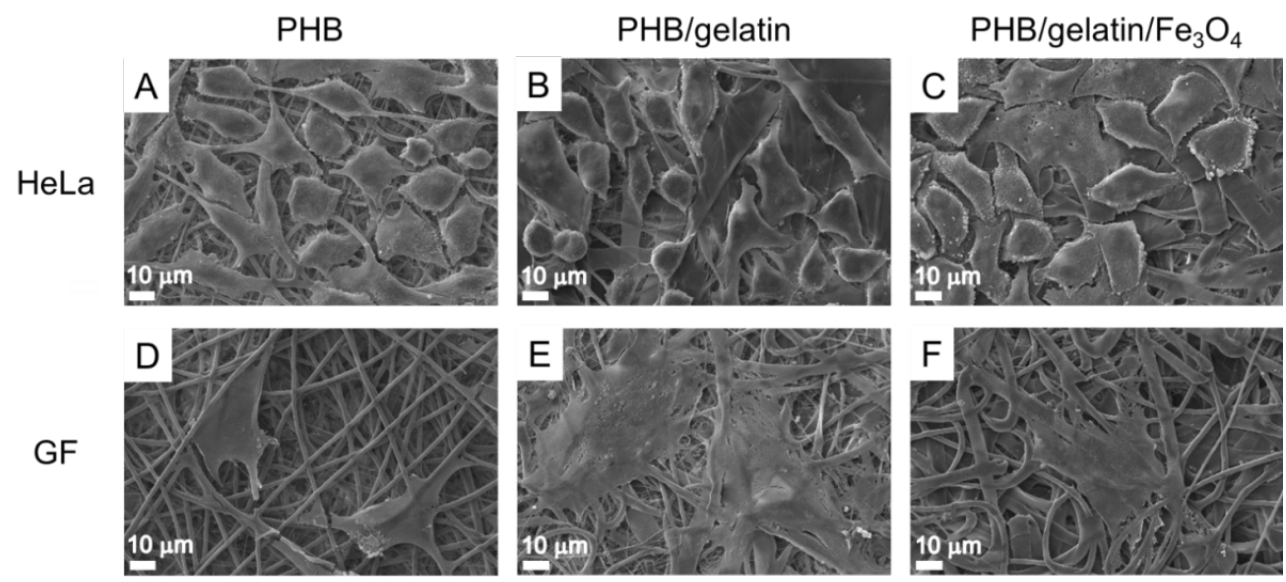

Figure 7. SEM images of HeLa (A-C) and GF (D-F) cell adhesion to PHB, PHB/gelatin, PHB/ gelatin $/ \mathrm{Fe}_{3} \mathrm{O}_{4}$ scaffolds.

The interaction of cells with gelatin enriched scaffolds could be increased further via treatment with glutaraldehyde, which allows a decrease in the molecular mobility of the surface exposed gelatin and thus provides better cell adhesion, as reported elsewhere [67]. Thus, the results presented demonstrated biocompatibility of the developed PHB-based scaffolds and the possibility of their use in the different biological systems.

\section{Conclusions}

Hybrid electrospun $\mathrm{PHB} /$ gelatin and $\mathrm{PHB} /$ gelatin/ $\mathrm{Fe}_{3} \mathrm{O}_{4}$ and pure $\mathrm{PHB}$ scaffolds were synthesized and their morphology, structure, phase composition, thermal, magnetic, and biological properties were studied. The obtained scaffolds showed randomly oriented microfibers with an average diameter $1.75 \pm 0.26 \mu \mathrm{m}, 2.33 \pm 1.38 \mu \mathrm{m}$ and $5.65 \pm 1.23 \mu \mathrm{m}$ for $\mathrm{PHB}, \mathrm{PHB} /$ gelatin and $\mathrm{PHB} /$ gelatin $/ \mathrm{Fe}_{3} \mathrm{O}_{4}$ scaffolds, respectively. The incorporation of gelatin to PHB composites resulted in the formation of core-shell fibers (PHB-core, gelatin-shell) due to phase separation (thermodynamic immiscibility of both polymers) 
and its polyelectrolyte nature. The core-shell morphology of the fabricated composite scaffolds was confirmed by XPS, DSC and optical microscopy. The formation of coreshell structure in the case of $\mathrm{PHB} /$ gelatin and $\mathrm{PHB} /$ gelatin $/ \mathrm{Fe}_{3} \mathrm{O}_{4}$ scaffolds resulted in a decrease in crystallinity (and crystallite size) of the PHB phase from $52.3 \%(31 \mathrm{~nm})$ in pure $\mathrm{PHB}$ to $16.9 \%(27 \mathrm{~nm})$ in $\mathrm{PHB} /$ gelatin and $9.2 \%(21 \mathrm{~nm})$ in $\mathrm{PHB} /$ gelatin $/ \mathrm{Fe}_{3} \mathrm{O}_{4}$ scaffolds due to the confinement effect. Saturation magnetization of $\mathrm{PHB} /$ gelatin $/ \mathrm{Fe}_{3} \mathrm{O}_{4}$ scaffolds $3.27 \pm 0.22 \mathrm{emu} / \mathrm{g}$ was in the range of $2-5 \mathrm{emu} / \mathrm{g}$, as reported in the literature, as an optimal for magnetoactive materials. The cytotoxicity study of electrospun scaffolds demonstrated that both human cervix adenocarcinoma HeLa cells and human primary fibroblasts revealed a similar cellular response to the extracts, which were not statistically different from the control and thus allow scaffolds to be considered non-toxic to cells. The data obtained by the cultivation of cells on the scaffolds in vitro did not reveal the pronounced effect of scaffold composition on cell adhesion and growth. Thus, the prepared magnetoactive hybrid scaffolds of $\mathrm{PHB} /$ gelatin $/ \mathrm{Fe}_{3} \mathrm{O}_{4}$ can be potentially used as magnetoresponsive materials for tissue engineering, wound dressing, and controlled drug delivery using an external magnetic field.

Supplementary Materials: The following supporting information can be downloaded at: https: / / www.mdpi.com/article/10.3390/polym14030529/s1, Figure S1: SEM image (A) and particle size distribution (B) of $\mathrm{Fe}_{3} \mathrm{O}_{4}$; Figure S2: XRD patterns (A) and Raman spectrum (B) of $\mathrm{Fe}_{3} \mathrm{O}_{4}$; Figure S3: Survey and high-resolution XPS spectra (A) of the C 1s (B), O 1s (C) and N 1s (D) regions for as-electrospun scaffolds and scaffolds after immersion in saline solution for $3 \mathrm{~h}$.

Author Contributions: Conceptualization, A.S.P. and P.P.L.; methodology, D.V.W., V.S.C. and M.A.S.; validation, Y.R.M.; investigation, V.V.B., Y.R.M., I.P., R.A.S., M.A.S., and B.P.C.; writing-original draft preparation, A.S.P., V.V.B., R.A.S., M.A.S. and R.V.C.; writing-review and editing, A.L.K. and R.A.S.; supervision, A.L.K. and R.A.S.; funding acquisition, A.L.K. All authors have read and agreed to the published version of the manuscript.

Funding: The financial support from the Ministry of Science and Higher Education of the Russian Federation is acknowledged (grant agreement \#075-15-2021-588 from 1.06.2021). The research was carried out at Tomsk Polytechnic University within the framework of Tomsk Polytechnic University development program (infrastructural support). Part of this work was developed within the scope of the project CICECO-Aveiro Institute of Materials, UIDB/50011/2020 \& UIDP/50011/2020, financed by national funds through the Portuguese Foundation for Science and Technology/MCTE. SEM study was funded by the Russian State-funded budget project of ICBFM SB RAS number 121031300042-1.

Institutional Review Board Statement: Not applicable.

Data Availability Statement: The data presented in this study are available on request from the corresponding author.

Acknowledgments: The authors thank the central laboratories of TPU (Analytical Center) for the XPS measurements.

Conflicts of Interest: The authors declare no conflict of interest.

\section{References}

1. Manouras, T.; Vamvakaki, M. Field responsive materials: Photo-, electro-, magnetic-and ultrasound-sensitive polymers. Polym. Chem. 2017, 8, 74-96. [CrossRef]

2. Adedoyin, A.A.; Ekenseair, A.K. Biomedical applications of magneto-responsive scaffolds. Nano Res. 2018, 11, 5049-5064. [CrossRef]

3. Thévenot, J.; Oliveira, H.; Sandre, O.; Lecommandoux, S. Magnetic responsive polymer composite materials. Chem. Soc. Rev. 2013, 42, 7099-7116. [CrossRef]

4. Jingcheng, L.; Reddy, V.S.; Jayathilaka, W.A.; Chinnappan, A.; Ramakrishna, S.; Ghosh, R. Intelligent Polymers, Fibers and Applications. Polymers 2021, 13, 1427. [CrossRef]

5. Zhang, C.; Li, X.; Jiang, L.; Tang, D.; Xu, H.; Zhao, P.; Fu, J.; Zhou, Q.; Chen, Y. 3D Printing of Functional Magnetic Materials: From Design to Applications. Adv. Funct. Mater. 2021, 31, 2102777. [CrossRef] 
6. Sharifianjazi, F.; Irani, M.; Esmaeilkhanian, A.; Bazli, L.; Asl, M.S.; Jang, H.W.; Kim, S.Y.; Ramakrishna, S.; Shokouhimehr, M.; Varma, R.S. Polymer incorporated magnetic nanoparticles: Applications for magnetoresponsive targeted drug delivery. Mater. Sci. Eng. B 2021, 272, 115358. [CrossRef]

7. Mmelesi, O.K.; Masunga, N.; Kuvarega, A.; Nkambule, T.T.; Mamba, B.B.; Kefeni, K.K. Cobalt ferrite nanoparticles and nanocomposites: Photocatalytic, antimicrobial activity and toxicity in water treatment. Mater. Sci. Semicond. Process. 2021, 123, 105523. [CrossRef]

8. Niculescu, A.-G.; Chircov, C.; Grumezescu, A.M. Magnetite nanoparticles: Synthesis methods-A comparative review. Methods, 2021; in press. [CrossRef]

9. Mai, B.T.; Fernandes, S.; Balakrishnan, P.B.; Pellegrino, T. Nanosystems based on magnetic nanoparticles and thermo-or pHresponsive polymers: An update and future perspectives. Acc. Chem. Res. 2018, 51, 999-1013. [CrossRef]

10. Petcharoen, K.; Sirivat, A. Magneto-electro-responsive material based on magnetite nanoparticles/polyurethane composites. Mater. Sci. Eng. C 2016, 61, 312-323. [CrossRef]

11. Liu, F.; Li, M.; Li, F.; Weng, K.; Qi, K.; Liu, C.; Ni, Q.; Tao, X.; Zhang, J.; Shao, W. Preparation and properties of PVDF/Fe ${ }_{3} \mathrm{O}_{4}$ nanofibers with magnetic and electret effects and their application in air filtration. Macromol. Mater. Eng. 2020, 305, 1900856. [CrossRef]

12. Yao, L.; Wang, Y.; Li, Y.; Jiang, Z.; Qiu, D. Controlled preparation of $\mathrm{Fe}_{3} \mathrm{O}_{4} /$ PLA composites and their properties. Chem. Pap. 2021, 75, 6399-6406. [CrossRef]

13. Pryadko, A.; Surmeneva, M.A.; Surmenev, R.A. Review of Hybrid Materials Based on Polyhydroxyalkanoates for Tissue Engineering Applications. Polymers 2021, 13, 1738. [CrossRef] [PubMed]

14. Grigore, M.E.; Grigorescu, R.M.; Iancu, L.; Ion, R.-M.; Zaharia, C.; Andrei, E.R. Methods of synthesis, properties and biomedical applications of polyhydroxyalkanoates: A review. J. Biomater. Sci. Polym. Ed. 2019, 30, 695-712. [CrossRef]

15. Goonoo, N.; Bhaw-Luximon, A.; Passanha, P.; Esteves, S.R.; Jhurry, D. Third generation poly (hydroxyacid) composite scaffolds for tissue engineering. J. Biomed. Mater. Res. Part B 2017, 105, 1667-1684. [CrossRef] [PubMed]

16. Degli Esposti, M.; Chiellini, F.; Bondioli, F.; Morselli, D.; Fabbri, P. Highly porous PHB-based bioactive scaffolds for bone tissue engineering by in situ synthesis of hydroxyapatite. Mater. Sci. Eng. C 2019, 100, 286-296. [CrossRef] [PubMed]

17. Babos, G.; Rydz, J.; Kawalec, M.; Klim, M.; Fodor-Kardos, A.; Trif, L.; Feczkó, T. Poly (3-hydroxybutyrate)-based nanoparticles for sorafenib and doxorubicin anticancer drug delivery. Int. J. Mol. Sci. 2020, 21, 7312. [CrossRef]

18. Raza, Z.A.; Khalil, S.; Abid, S. Recent progress in development and chemical modification of poly (hydroxybutyrate)-based blends for potential medical applications. Int. J. Biol. Macromol. 2020, 160, 77-100. [CrossRef]

19. Chernozem, R.; Surmeneva, M.; Shkarina, S.; Loza, K.; Epple, M.; Ulbricht, M.; Cecilia, A.; Krause, B.; Baumbach, T.; Abalymov, A. Piezoelectric 3-D fibrous poly (3-hydroxybutyrate)-based scaffolds ultrasound-mineralized with calcium carbonate for bone tissue engineering: Inorganic phase formation, osteoblast cell adhesion, and proliferation. ACS Appl. Mater. Interfaces 2019, 11, 19522-19533. [CrossRef]

20. Mu, J. Three-Dimensional Hybrid Piezoelectric Polymer-Based Scaffolds for Regenerative Medicine and Biosensors. Doctoral Thesis, University of California, Riverside, CA, USA, 2020.

21. Sangsanoh, P.; Supaphol, P. Poly (3-hydroxybutyrate)/magnetite composite nanofibers obtained via combined electrospinning and ammonia gas-enhancing in situ co-precipitation: Preparation and potential use in biomedical applications. Chiang Mai J. Sci. 2014, 41, 676-690.

22. Ho, M.H.; Li, S.Y.; Ciou, C.Y.; Wu, T.M. The morphology and degradation behavior of electrospun poly (3-hydroxybutyrate)/Magnetite and poly (3-hydroxybutyrate-co-3-hydroxyvalerate)/Magnetite composites. J. Appl. Polym. Sci. 2014, 131, 41070. [CrossRef]

23. Kokkinis, D.; Schaffner, M.; Studart, A.R. Multimaterial magnetically assisted 3D printing of composite materials. Nat. Commun. 2015, 6, 8643. [CrossRef] [PubMed]

24. Sapir-Lekhovitser, Y.; Rotenberg, M.Y.; Jopp, J.; Friedman, G.; Polyak, B.; Cohen, S. Magnetically actuated tissue engineered scaffold: Insights into mechanism of physical stimulation. Nanoscale 2016, 8, 3386-3399. [CrossRef] [PubMed]

25. Fuhrer, R.; Hofmann, S.; Hild, N.; Vetsch, J.R.; Herrmann, I.K.; Grass, R.N.; Stark, W.J. Pressureless mechanical induction of stem cell differentiation is dose and frequency dependent. PLoS ONE 2013, 8, e81362. [CrossRef] [PubMed]

26. Shuai, C.; Cheng, Y.; Yang, W.; Feng, P.; Yang, Y.; He, C.; Qi, F.; Peng, S. Magnetically actuated bone scaffold: Microstructure, cell response and osteogenesis. Compos. Part B 2020, 192, 107986. [CrossRef]

27. Lin, H.-Y.; Huang, H.-Y.; Shiue, S.-J.; Cheng, J.-K. Osteogenic effects of inductive coupling magnetism from magnetic 3D printed hydrogel scaffold. J. Magn. Magn. Mater. 2020, 504, 166680. [CrossRef]

28. Fernandes, M.M.; Correia, D.M.; Ribeiro, C.; Castro, N.; Correia, V.; Lanceros-Mendez, S. Bioinspired three-dimensional magnetoactive scaffolds for bone tissue engineering. ACS Appl. Mater. Interfaces 2019, 11, 45265-45275. [CrossRef]

29. Soares, P.I.; Romao, J.; Matos, R.; Silva, J.C.; Borges, J.P. Design and engineering of magneto-responsive devices for cancer theranostics: Nano to macro perspective. Prog. Mater. Sci. 2021, 116, 100742. [CrossRef]

30. Adedoyin, A.A.; Ekenseair, A.K. Magneto-responsive scaffolds for tissue engineering applications. In The Road from Nanomedicine to Precision Medicine; Jenny Stanford Publishing: Singapore, 2020; pp. 559-575.

31. Shrivastav, A.; Kim, H.-Y.; Kim, Y.-R. Advances in the applications of polyhydroxyalkanoate nanoparticles for novel drug delivery system. BioMed Res. Int. 2013, 2013, 581684. [CrossRef] 
32. Hassan, M.A.; Amara, A.A.; Abuelhamd, A.T.; Haroun, B.M. Leucocytes show improvement growth on PHA polymer surface. Pak. J. Pharm. Sci 2010, 23, 332-336.

33. Naderi, P.; Zarei, M.; Karbasi, S.; Salehi, H. Evaluation of the effects of keratin on physical, mechanical and biological properties of poly (3-hydroxybutyrate) electrospun scaffold: Potential application in bone tissue engineering. Eur. Polym. J. 2020, 124, 109502. [CrossRef]

34. Alipal, J.; Pu'ad, N.M.; Lee, T.; Nayan, N.; Sahari, N.; Basri, H.; Idris, M.; Abdullah, H. A review of gelatin: Properties, sources, process, applications, and commercialisation. Mater. Today Proc. 2021, 42, 240-250. [CrossRef]

35. Bidone, J.; Melo, A.P.P.; Bazzo, G.C.; Carmignan, F.; Soldi, M.S.; Pires, A.T.; Lemos-Senna, E. Preparation and characterization of ibuprofen-loaded microspheres consisting of poly (3-hydroxybutyrate) and methoxy poly (ethylene glycol)-b-poly (D, L-lactide) blends or poly (3-hydroxybutyrate) and gelatin composites for controlled drug release. Mater. Sci. Eng. C 2009, 29, 588-593. [CrossRef]

36. Nagiah, N.; Madhavi, L.; Anitha, R.; Srinivasan, N.T.; Sivagnanam, U.T. Electrospinning of poly (3-hydroxybutyric acid) and gelatin blended thin films: Fabrication, characterization, and application in skin regeneration. Polym. Bull. 2013, 70, $2337-2358$. [CrossRef]

37. Sanhueza, C.; Hermosilla, J.; Bugallo-Casal, A.; Da Silva-Candal, A.; Taboada, C.; Millan, R.; Concheiro, A.; Alvarez-Lorenzo, C.; Acevedo, F. One-step electrospun scaffold of dual-sized gelatin/poly-3-hydroxybutyrate nano/microfibers for skin regeneration in diabetic wound. Mater. Sci. Eng. C 2021, 119, 111602. [CrossRef]

38. Canetti, M.; Urso, M.; Sadocco, P. Influence of the morphology and of the supermolecular structure on the enzymatic degradation of bacterial poly (3-hydroxybutyrate). Polymer 1999, 40, 2587-2594. [CrossRef]

39. Chen, L.; Wang, M. Production and evaluation of biodegradable composites based on PHB-PHV copolymer. Biomaterials 2002, 23, 2631-2639. [CrossRef]

40. Kreslin, V.Y.; Naiden, E. Automatic complex for a study of the characteristics of hard magnetic materials. Instrum. Exp. Tech. 2002, 45, 55-57. [CrossRef]

41. Tamer, T.M.; Alsehli, M.H.; Omer, A.M.; Afifi, T.H.; Sabet, M.M.; Mohy-Eldin, M.S.; Hassan, M.A. Development of Polyvinyl Alcohol/Kaolin Sponges Stimulated by Marjoram as Hemostatic, Antibacterial, and Antioxidant Dressings for Wound Healing Promotion. Int. J. Mol. Sci. 2021, 22, 13050. [CrossRef]

42. Topuz, F.; Uyar, T. Electrospinning of gelatin with tunable fiber morphology from round to flat/ribbon. Mater. Sci. Eng. C 2017, 80, 371-378. [CrossRef]

43. Meng, Z.; Xu, X.; Zheng, W.; Zhou, H.; Li, L.; Zheng, Y.; Lou, X. Preparation and characterization of electrospun PLGA/gelatin nanofibers as a potential drug delivery system. Colloids Surf. B 2011, 84, 97-102. [CrossRef] [PubMed]

44. Ghasemi-Mobarakeh, L.; Prabhakaran, M.P.; Morshed, M.; Nasr-Esfahani, M.-H.; Ramakrishna, S. Electrospun poly ( $\varepsilon-$ caprolactone)/gelatin nanofibrous scaffolds for nerve tissue engineering. Biomaterials 2008, 29, 4532-4539. [CrossRef] [PubMed]

45. Li, J.; Hong, R.; Li, H.; Ding, J.; Zheng, Y.; Wei, D. Simple synthesis and magnetic properties of $\mathrm{Fe}_{3} \mathrm{O}_{4} / \mathrm{BaSO}_{4} \mathrm{multi}^{-c o r e} / \mathrm{shell}$ particles. Mater. Chem. Phys. 2009, 113, 140-144. [CrossRef]

46. Chowdhury, T.; D'Souza, N.; Berman, D. Electrospun $\mathrm{Fe}_{3} \mathrm{O}_{4}-\mathrm{PVDF}$ Nanofiber Composite Mats for Cryogenic Magnetic Sensor Applications. Textiles 2021, 1, 227-238. [CrossRef]

47. Phongtamrug, S.; Tashiro, K. X-ray Crystal Structure Analysis of Poly (3-hydroxybutyrate) $\beta$-Form and the Proposition of a Mechanism of the Stress-Induced $\alpha$-to- $\beta$ Phase Transition. Macromolecules 2019, 52, 2995-3009. [CrossRef]

48. Meade, A.D.; Lyng, F.M.; Knief, P.; Byrne, H.J. Growth substrate induced functional changes elucidated by FTIR and Raman spectroscopy in in-vitro cultured human keratinocytes. Anal. Bioanal. Chem. 2007, 387, 1717-1728. [CrossRef]

49. Chernozem, R.V.; Romanyuk, K.N.; Grubova, I.; Chernozem, P.V.; Surmeneva, M.A.; Mukhortova, Y.R.; Wilhelm, M.; Ludwig, T.; Mathur, S.; Kholkin, A.L. Enhanced piezoresponse and surface electric potential of hybrid biodegradable polyhydroxybutyrate scaffolds functionalized with reduced graphene oxide for tissue engineering. Nano Energy 2021, 89, 106473. [CrossRef]

50. Jingrun, R.; Jin, W.; Hong, S.; Nan, H. Surface modification of polyethylene terephthalate with albumin and gelatin for improvement of anticoagulation and endothelialization. Appl. Surf. Sci. 2008, 255, 263-266. [CrossRef]

51. De Giglio, E.; Ditaranto, N.; Sabbatini, L. 3. Polymer surface chemistry: Characterization by XPS. In Polymer Surface Characterization; De Gruyter: Berlin, Germany, 2014; pp. 73-112.

52. Nitschke, M.; Schmack, G.; Janke, A.; Simon, F.; Pleul, D.; Werner, C. Low pressure plasma treatment of poly(3-hydroxybutyrate): Toward tailored polymer surfaces for tissue engineering scaffolds. J. Biomed. Mater. Res. 2002, 59, 632-638. [CrossRef]

53. Ma, W.; Yang, P.; Zhao, Y.; Huang, N. Biomimetic GelMPC Micropatterns on Titanium and Their Effects on Platelets and Endothelialization. Adv. Eng. Mater. 2018, 20, 1800624. [CrossRef]

54. Yuan, S.; Xiong, G.; Roguin, A.; Teoh, S.H.; Choong, C. Amelioration of blood compatibility and endothelialization of polycaprolactone substrates by surface-initiated atom transfer radical polymerization. In Advances in Biomaterials Science and Biomedical Applications; Pignatello, R., Ed.; IntechOpen: London, UK, 2013; pp. 177-205.

55. Hou, X.; Zhang, B.-L.; She, F.; Cui, Y.-L.; Shi, K.-Y.; Yao, K.-D. Surface of gelatin modified poly(L-lactic acid) film. Chin. J. Polym. Sci. 2003, 21, 277-284. 
56. Nagiah, N.; Madhavi, L.; Anitha, R.; Anandan, C.; Srinivasan, N.T.; Sivagnanam, U.T. Development and characterization of coaxially electrospun gelatin coated poly (3-hydroxybutyric acid) thin films as potential scaffolds for skin regeneration. Mater. Sci. Eng. C 2013, 33, 4444-4452. [CrossRef] [PubMed]

57. Abdullah, M.F.; Nuge, T.; Andriyana, A.; Ang, B.C.; Muhamad, F. Core-shell fibers: Design, roles, and controllable release strategies in tissue engineering and drug delivery. Polymers 2019, 11, 2008. [CrossRef] [PubMed]

58. Xu, T.; Yang, H.; Yang, D.; Yu, Z.-Z. Polylactic Acid Nanofiber Scaffold Decorated with Chitosan Islandlike Topography for Bone Tissue Engineering. ACS Appl. Mater. Interfaces 2017, 9, 21094-21104. [CrossRef] [PubMed]

59. Zhang, Y.Z.; Venugopal, J.; Huang, Z.-M.; Lim, C.T.; Ramakrishna, S. Crosslinking of the electrospun gelatin nanofibers. Polymer 2006, 47, 2911-2917. [CrossRef]

60. Upadhyay, S.; Parekh, K.; Pandey, B. Influence of crystallite size on the magnetic properties of $\mathrm{Fe}_{3} \mathrm{O}_{4}$ nanoparticles. J. Alloys Compd. 2016, 678, 478-485. [CrossRef]

61. Hao, L.; Li, L.; Wang, P.; Wang, Z.; Shi, X.; Guo, M.; Zhang, P. Synergistic osteogenesis promoted by magnetically actuated nano-mechanical stimuli. Nanoscale 2019, 11, 23423. [CrossRef]

62. Cai, Q.; Shi, Y.; Shan, D.; Jia, W.; Duan, S.; Deng, X.; Yang, X. Osteogenic differentiation of MC3T3-E1 cells on poly(l-lactide)/Fe $3 \mathrm{O}_{4}$ nanofibers with static magnetic field exposure. Mater. Sci. Eng. C 2015, 55, 166-173. [CrossRef]

63. Yun, H.-M.; Ahn, S.-J.; Park, K.-R.; Kim, M.-J.; Kim, J.-J.; Jin, G.-Z.; Kim, H.-W.; Kim, E.-C. Magnetic nanocomposite scaffolds combined with static magnetic field in the stimulation of osteoblastic differentiation and bone formation. Biomaterials 2016, 85 , 88-98. [CrossRef]

64. Smit, J.; Wijn, H.P.J. Ferrites; Philips Technical Library: Eindhoven, The Netherlands, 1959.

65. Rees, K.R. Cells in Culture in Toxicity Testing: A Review. J. R. Soc. Med. 1980, 73, 261-264. [CrossRef]

66. Chernonosova, V.S.; Kvon, R.I.; Stepanova, A.O.; Larichev, Y.V.; Karpenko, A.A.; Chelobanov, B.P.; Kiseleva, E.V.; Laktionov, P.P. Human serum albumin in electrospun PCL fibers: Structure, release, and exposure on fiber surface. Polym. Adv. Technol. 2016, 28, 819-827. [CrossRef]

67. Chernonosova, V.S.; Gostev, A.A.; Gao, Y.; Chesalov, Y.A.; Shutov, A.V.; Pokushalov, E.A.; Karpenko, A.A.; Laktionov, P.P. Mechanical Properties and Biological Behavior of 3D Matrices Produced by Electrospinning from Protein-Enriched Polyurethane. BioMed Res. Int. 2018, 2018, 1380606. [CrossRef] [PubMed]

68. Akkas, T.; Citak, C.; Sirkecioglu, A.; Güner, F.S. Which is more effective for protein adsorption: Surface roughness, surface wettability or swelling? Case study of polyurethane films prepared from castor oil and poly(ethylene glycol). Polym. Int. 2012, 62, 1202-1209. [CrossRef]

69. Vogler, E.A. Protein adsorption in three dimensions. Biomaterials 2012, 33, 1201-1237. [CrossRef] [PubMed]

70. Zeugolis, D.I.; Khew, S.T.; Yew, E.S.Y.; Ekaputra, A.K.; Tong, Y.W.; Yung, L.-Y.L.; Hutmacher, D.W.; Sheppar, C.; Raghunath, M. Electro-spinning of pure collagen nano-fibres-Just an expensive way to make gelatin? Biomaterials 2008, 29, $2293-2305$. [CrossRef]

71. Kennedy, K.M.; Bhaw-Luximon, A.; Jhurry, D. Cell-matrix mechanical interaction in electrospun polymeric scaffolds for tissue engineering: Implications for scaffold design and performance. Acta Biomater. 2017, 50, 41-55. [CrossRef]

72. Chung, T.-W.; Liu, D.-Z.; Wang, S.-Y.; Wang, S.-S. Enhancement of the growth of human endothelial cells by surface roughness at nanometer scale. Biomaterials 2003, 24, 4655-4661. [CrossRef]

73. Xu, C.; Yang, F.; Wang, S.; Ramakrishna, S. In vitro study of human vascular endothelial cell function on materials with various surface roughness. J. Biomed. Mater. Res. 2004, 71A, 154-161. [CrossRef]

74. Di Cio, S.; Gautrot, J.E. Cell sensing of physical properties at the nanoscale: Mechanisms and control of cell adhesion and phenotype. Acta Biomater. 2016, 30, 26-48. [CrossRef]

75. Lowery, J.L.; Datta, N.; Rutledge, G.C. Effect of fiber diameter, pore size and seeding method on growth of human dermal fibroblasts in electrospun poly( $\varepsilon$-caprolactone) fibrous mats. Biomaterials 2010, 31, 491-504. [CrossRef] 